\title{
Nutrients Dissolution Kinetics of Aerosols at Qianliyan Island, the Yellow Sea by a High \\ Time-resolution Nutrient Dissolution Experiment, Potential Linkages with Inorganic Compositions and $P$ solubility controlled factors
}

Ke Zhang ${ }^{1,2}$, Lijun Han ${ }^{1,3}$, Sumei Liu ${ }^{1,2}$, Lingyan Wang ${ }^{1,2}$

${ }^{1}$ Key Laboratory of Marine Chemistry Theory and Technology MOE/College of Chemistry and Chemical Engineering, Ocean University of China, Qingdao 266100, China

${ }^{2}$ Laboratory for Marine Ecology and Environmental Science, Qingdao National Laboratory for Marine Science and Technology, Qingdao 266237, China

${ }^{3}$ Present at Hebei Province Environmental Monitoring Center

Correspondence: Sumei Liu (sumeiliu@ouc.edu.cn)

\section{Graphic abstract:}

\section{Nutrient release of aerosol particles in diverse water conditions}
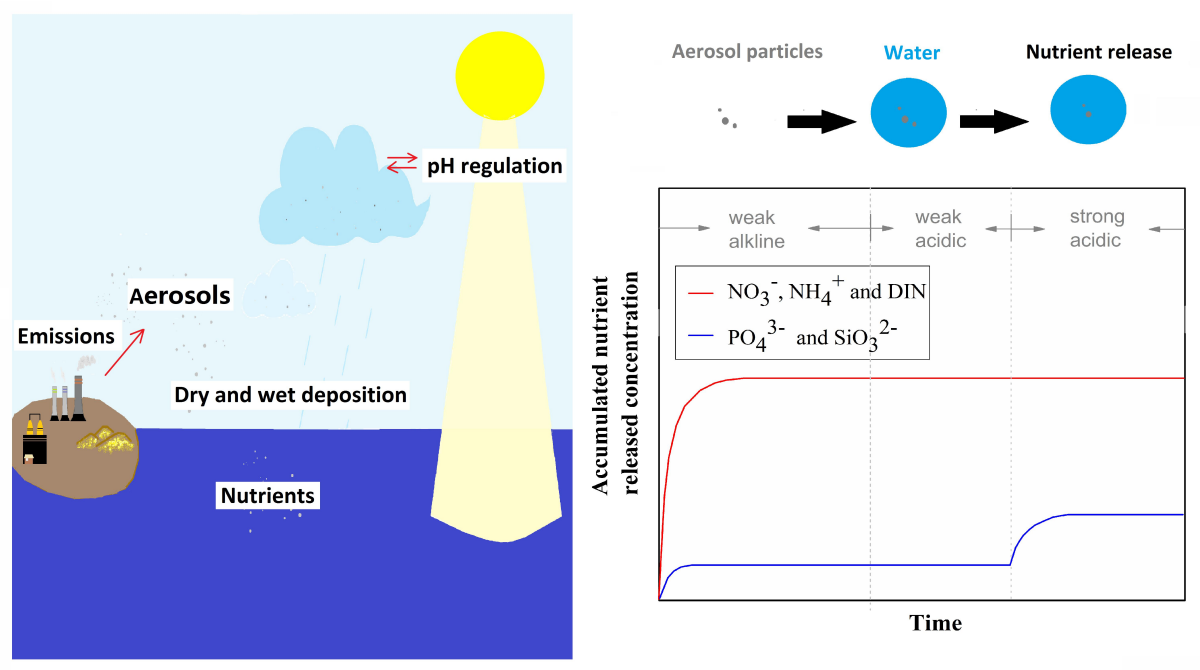

Abstract. A series of high time-resolution nutrient dissolution experiments were designed to determine the soluble fraction of atmospheric nutrients and reveal the short-time dissolution processes, patterns and kinetics of nutrient elements in aerosols. Aerosols that represented an important part of atmospheric transport path over the East Asian to West Pacific were leached by Milli-Q water and aged seawater at gradient $\mathrm{pHs}$ for certain time duration. Varied nutrient dissolution curves indicated that 
aerosol inorganic $\mathrm{N}, \mathrm{P}$ and $\mathrm{Si}$ species dissolution reactions were quasi-first-order. Particularly, prominent factors influenced $\mathrm{P}$ solubility were source and acidity. Ratios of acid-soluble to water-soluble nutrient concentrations in high time-resolution dissolution experiments and ultra-sound extractions were $1.0(0.9-1.1)$ for $\mathrm{NH}_{4}^{+}$and $\mathrm{NO}_{3}^{-}, 2.4$ (2.1-2.6) for $\mathrm{PO}_{4}{ }^{3-}$ and 2.5 for $\mathrm{SiO}_{3}{ }^{2-}$, demonstrating that inorganic $\mathrm{N}$ species were inclined to immediate and complete dissolution due to fine particles formed by gas-particle transformation, inorganic P (Fe-P, Ca-P and De-P) and Si were tended to dissolve more in strong acidity mainly because of coarse soil-derived mineral particles. Compared with the slow dissolution of inorganic $\mathrm{P}$ and $\mathrm{Si}$, the rapid dissolution of inorganic $\mathrm{N}$ can affect the composition of marine nutrients and marine primary productivity.

\section{Introduction}

Atmospheric deposition supplies dissolved or particulate nutrients onto the surface ocean, which is a vital source of nutrient transportation into ocean (Duce et al., 2008; Guieu et al., 2010). Also, atmospheric deposition enhances marine primary production, showing potential linkages with phytoplankton growth and their community structures (Doney, 2010; Anderson et al., 2011; Nenes et al., 2011; Tréguer et al., 2013; Guieu et al., 2015; Siswanto, 2015).

For both marginal seas and oceans, atmospheric deposition is of great significance, so atmospheric deposition flux is wildly proposed to assess aerosol nutrient levels. The molar nutrient concentrations in aerosols used for calculations of atmospheric deposition dry flux are extracted by diverse methods. The prevailing extraction method was ultrasonic extraction method using Milli-Q water with different time in-length $(0.5-1 \mathrm{~h})$ at $0^{\circ} \mathrm{C}$ or at room temperature (Cornell et al., 1995; Nakamura et al., 2005; Shi et al., 2010; Qi et al., 2017). Except for ultrasound methods, a mini-loop circulation system was invented to measure aerosol soluble fraction (Eyckmans et al., 2001). However, these extraction conditions do not directly reproduce those under which aerosol components would be released into seawater. Few studies have showed the concern about the comparisons between pure-water and seawater-soluble nutrient 
concentrations of aerosols since last two decades. For major $\mathrm{N}$ species, no significant differences were

observed between pure-water and seawater extractions (Chen et al., 2006; Kocak, 2015). It was a pity that results for soluble P in pure-water and seawater were controversial (Markaki et al., 2003; Chen et al., 2006; Kocak, 2015). Study of Markaki et al. (2003) indicated no statistical difference, on the contrary, studies of Chen et al. (2006) and Kocak (2015) revealed that dissolution of $\mathrm{PO}_{4}{ }^{3-}$ in seawater were $11 \%$ and $52 \%$ lower than that in pure water. For soluble Si, Kocak (2015) showed that dissolution of $\mathrm{SiO}_{3}{ }^{2-}$ in seawater was $66 \%$ lower than that in pure water.

Aerosol soluble P and Si data were scarce compared to soluble N species, so researches focused on $\mathrm{P}$ and Si solubility under the assumption that phytoplankton prefers soluble nutrients. Regardless of different extractions, P solubility of Atlantic ocean aerosol, Saharan and Asian dust aerosols were 32\% (0.01-87\%), 8\% (2.3-67\%) and 37\% (9.3-90\%), respectively (Baker et al., 2006a; Baker et al., 2006b; Wang et al.,2017). Si solubility of Saharan aerosol and Asian dust aerosol ranged 0.12\% (0.02-1.1\%) and $0.16 \%(0.02-0.74 \%)$ (Baker et al., 2006b; Wang et al.,2017). These assessments of solubility gave a general view of solubilisation, contributing to simple biogeochemical model (Harrison, 2000; Krishnamurthy et al., 2010), arising attentions on aerosol nutrient accretions via atmospheric transfer path (Anderson et al., 2010; Nenes et al., 2011). Nevertheless, aforementioned investigations did not further dig into dissolution kinetics, so more information could be given when considered dissolved nutrient concentrations as a function of time and $\mathrm{pH}$. Long-time (72h) laboratory leaching experiments tested aerosol P dissolution kinetic as a function of time, showing 2-9 fold soluble P increase after $72 \mathrm{~h}$ compared with initial soluble P concentration (Mackey et al., 2012). Besides, long-time (48h) batch dissolution experiments and short-time (60s) step-by-step dissolution experiments that setting a series of descending $\mathrm{pH}$ gradients, of which both using aerosol precursors that tested $\mathrm{P}$ dissolution kinetic as a single variable of $\mathrm{pH}$, could quantified the $\mathrm{H}^{+}$concentration threshold value that aerosol precursors started dissolved and soluble P increased 6 times (Aghnatios et al., 2014; Stockdale et al., 2016). Moreover, short-time (75min) nutrient dissolution experiments using modified mini-loop system that 
monitored dissolution process in greater detail via high time-resolution were presented acid promotion,

solubility and successive observational results, which could make dissolution process be modeled and give the dissolution rate, dissolution equation information (Wang et al.,2017). However, these dissolution kinetic studies wholly used Milli-Q water as leaching solution, making the scenario of seawater dissolution kinetics of aerosols virtually unknown.

A strong gradient of heavy atmospheric $\mathrm{N}$ depositions from East Asian to light atmospheric $\mathrm{N}$ depositions in the central Pacific Ocean had been reported (Zhang et al., 2011). Our undeveloped sampling site, Qianliyan island, was on the atmospheric transport path over the East Asian to West Pacific, so it was an excellent location for aerosol collection and regional study. In this study, we aimed to investigate the magnitude of aerosol nutrient concentrations, the pattern of aerosol nutrients dissolution and controls of P solubility of aerosols, of which particular interest is the design to model the dissolution curves that providing details about short-time dissolution kinetics. Experiments were carried out using aerosols collected at Qianliyan island to mimic aerosol dissolution process in natural water (sea water and atmospheric water) undergone different $\mathrm{pH}$ conditions in the face of soaring anthropogenic emissions and climate change.

\section{Material and Methods}

\subsection{Site Description, Sample Collection and Sample Selection}

Qianliyan island $\left(36^{\circ} 16^{\prime} \mathrm{N}, 120^{\circ} 23^{\prime} \mathrm{E}\right)$, as a uninhabited sampling site over the north-west Yellow Sea, was under downwind area of heavy anthropogenic emissions in winter (Liu et al., 2012) and Asian dust transport in spring and summer (Zhang et al., 2003; Uno et al., 2009; Gao et al., 2014; Tao et al., 1987; Huang et al., 2007). Avoided unnecessary interference from nearby pollution sources, this island was an excellent sampling site, but the hard conditions on the island made it difficult to get samples.

Aerosols were weekly collected from January to July in 2011 and from March to October in 2012 at the top of Qianliyan Island (93.5 meters above sea level) by a high-volume sampler (KC-1000, 
LAOSHAN MOUNTAIN ELECTRONIC INSTRUMENT FACTORY CO., LTD.). The discontinuity of aerosol collection from August, 2011 to February, 2012 was caused by power supply problem.Total suspended particulate (TSP) samples were collected using standard poly-carbonate filters in 2011 and Whatman 41 cellulose fiber filters in 2012. Both filters are reported being suitable for TSP collection and chemical analysis. These filters were acidic cleaned by hydro-chloride acid solution $\left(0.01 \mathrm{~mol}^{\left.-\mathrm{L}^{-1}\right)}\right.$ and washed acid out until the same $\mathrm{pH}$ as Milli-Q water. Then pretreated filters were clearfully loaded onto the filter holder under clean condition before sample collection. The flow rate was set $1.05 \mathrm{~m}^{3} \cdot \mathrm{min}^{-1}$ and total sampling time was $20 \mathrm{~h}$. Totally, 39 aerosols were collected.

Sample Selection was based on season and main source. In order to reduce the uncertainty of the variable direction of the air mass, all backward trajectories that computed by the Hysplist 4 software and integrated by the MeteoInfoMap software (Fig. 1) were based on the airborne backward trajectory of $72 \mathrm{~h}$ in the intervals of an hour at the height of $1000 \mathrm{~m}$, the lower height of marine atmospheric boundary layer (MABL). North-west (NW) was prevailing source direction in spring, autumn and winter (Fig. S1), which was consistent with the typical Asian monsoon transport direction. South-west (SW) was the second major source direction in spring with the characteristics of anthropogenic emissions in southern China. Therefore, six aerosols (spr-SW, spr-NW, sum-NW, aut-NW, win-NW1 and win-NW2) capturing seasonal main features were selected for high time-resolution dissolution experiments. From spring to early summer, enormous quantity of mineral dust particles caused by East Asian dust storms was lifted from arid and semi-arid regions in Northeast Asia and transported a long distance. As showed in Fig. 1, spr-NW aerosol was affected by an intense sandstorm from arid and semi-arid regions of Inner Mongolia and northern China (China Meteorological Administration, 2011) with high TSP mass concentration (Table S1); while other aerosols had not been reported to be affected 115 by sand-storms, among them, spr-SW aerosol was mainly from Jiangsu and Anhui provinces and transported over Shandong province, sum-NW and aut-NW aerosols were from Russia and transported through west-north China and both win-NW1 and win-NW2 aerosols were originated from the Inner 
Mongolia province.

\subsection{Ultra-sound Extraction and Chemical Analysis}

Aerosol sub-sample (one $47 \mathrm{~mm}$ diameter circle piece cut off from sampling filter) was extracted with Milli-Q water or a $\mathrm{HCl}$ solution $\left(1 \mathrm{~mol} \cdot \mathrm{L}^{-1}\right)$ for an hour at room temperature and then extraction was filtered through $0.45 \mu \mathrm{m}$ PES membrane. The nutrient concentrations of filtered extractions were measured by nutrient analyzer (SKALAR SAN ${ }^{\text {plus }}$, Skalar Analytical B.V.). The detection limits of $\mathrm{NH}_{4}{ }^{+}$, $\mathrm{NO}_{3}{ }^{-}, \mathrm{PO}_{4}{ }^{3-}$ and $\mathrm{SiO}_{3}{ }^{2-}$ were $0.23 \mu \mathrm{mol} \cdot \mathrm{L}^{-1}, 0.20 \mu \mathrm{mol} \cdot \mathrm{L}^{-1}, 0.01 \mu \mathrm{mol} \cdot \mathrm{L}^{-1}$ and $0.10 \mu \mathrm{mol} \cdot \mathrm{L}^{-1}$, respectively. The detection precision of $\mathrm{NH}_{4}{ }^{+}, \mathrm{NO}_{3}{ }^{-}, \mathrm{PO}_{4}{ }^{3-}$ and $\mathrm{SiO}_{3}{ }^{2-}$ were $2.6 \%, 2.2 \%, 1.2 \%$ and $1.4 \%$, respectively.

\subsection{High Time-resolution Dissolution Experiment}

High time-resolution dissolution experiment used a small-volume flow-through leaching system (Fig. 2) based on Eyckmans et al. (2001) with a non-closed loop. The device was exactly the same as the one used by Wang et al. (2017), but the experimental conditions that specifically referring to leaching solution types and $\mathrm{pHs}$ were different. To simulate the natural plots, aged sea water and Milli-Q water were used as analogs of surface seawater and atmospheric water, respectively. Under these natural plots, $\mathrm{pH}$ gradient from 7.8 to 5.5 to 2.0 were used to simulate the deterioration of environmental conditions. Specifically, Milli-Q water at $\mathrm{pH} 7.8,5.5$ and 2.0 simulated weak alkaline atmospheric water, unpolluted natural atmospheric water and extreme acidic atmospheric water, respectively. Atmospheric water like rainwater could be weak alkaline due to the presence of alkaline elements, such as $\mathrm{Ca}$ and $\mathrm{Mg}$, and weak acidic because of the equilibrium of water and $\mathrm{CO}_{2}$, but could not be strong acidic that having pH lower than 3 (Losno et al., 1991; Chen et al., 2006); however, atmospheric water like cloud water may reach such low $\mathrm{pH}$ value owing to high acid/water ratio and eastern Asian cloud water had been reached 1 (Meskhidze et al., 2003). Aged seawater at $\mathrm{pH}$ 7.8, 5.5, 2.0 simulated natural surface sea water, acidic seawater and extreme acidic seawater, respectively. The acidic seawater scenarios were 
unlikely to occur due to the buffering capacity of seawater when facing current oceanic acidification, but they did show the scenarios when oceanic acidification exceeded the marine buffering capacity and/or the effect of diverse ionic strength (IS) on nutrient dissolution. At the same time, high time-resolution dissolution experiment required a reasonable aerosol area and leaching volumes for the simulation of the atmospheric deposition over Yellow Sea. The surface SPM concentrations of the Yellow Sea were characterized by typically ranging from 1 to $10 \mathrm{mg} \cdot \mathrm{L}^{-1}$ in the central areas and up to $200 \mathrm{mg} \cdot \mathrm{L}^{-1}$ in coastal areas (Park et al., 2001; Dobrynin et al., 2009; Zhang et al., 2018). The particulate concentrations that total volume $(281.25 \mathrm{~mL})$ of leaching solution divided aerosol particle mass of each $17.3 \mathrm{~cm}^{2}$ sub-samples in leaching system were ranged from $4.9 \mathrm{mg} \cdot \mathrm{L}^{-1}$ to $34.8 \mathrm{mg} \cdot \mathrm{L}^{-1}$. Experimental simulated particular concentrations were lower than surface SPM concentrations of the Yellow Sea, so our settings of sample area, leaching speed and time were reasonable.

In our leaching system, aerosol sub-sample was put into a mini-volume container, leaching liquid was pumped through at a constant velocity of $2.5 \mathrm{~mL} \cdot \mathrm{min}^{-1}$ and disposal filter was set at the end of the device to keep particles excluded. Leaching liquid was either Milli-Q water or aged seawater with $\mathrm{pH}$ gradient from 7.8 to 5.5 to 2.0 . Basic or acid condition was adjusted by $\mathrm{NaOH}$ or $\mathrm{HCl}$ solution. Leachates were collected at a 90s interval. The leaching time periods that 45 min for $\mathrm{pH} \mathrm{7.8,30} \mathrm{min} \mathrm{for}$ $\mathrm{pH} 5.5$ and $37.5 \mathrm{~min}$ for $\mathrm{pH} 2.0$, could ensure leaching system had reached the dissolution balance. The nutrient concentrations in leachates were measured by nutrient analyzer. All operations were carried out at room temperature $\left(20 \pm 5^{\circ} \mathrm{C}\right)$. The sum of nutrient concentrations of all leachates in each aerosol from 0 to 75 minutes represented water-soluble nutrient concentrations and that from 0 to 112.5 minutes represented acid-soluble nutrient concentrations.

\subsection{SEDEX Method}

Modified SEDEX Method (Ruttenberg, 1992; Huerta-Diaz et al., 2005) was used for aerosol P form measurements. There were 4 steps ascribed as follows: Step 1: The sub-sample was firstly extracted $6 \mathrm{~h}$ 
by $15 \mathrm{~mL}$ citrate/dithionite/bicarbonate (CDB) mixture solution $\left(0.22 \mathrm{~mol} \cdot \mathrm{L}^{-1} \mathrm{C}_{6} \mathrm{H}_{5} \mathrm{Na}_{3} \mathrm{O}_{7}+1 \mathrm{~mol} \cdot \mathrm{L}^{-1}\right.$ $\left.\mathrm{NaHCO}_{3}+0.033 \mathrm{~mol} \cdot \mathrm{L}^{-1} \mathrm{Na}_{2} \mathrm{~S}_{2} \mathrm{O}_{4}\right)$ at $\mathrm{pH} 7.6$, then extracted $2 \mathrm{~h}$ by $15 \mathrm{~mL} \mathrm{MgCl}_{2}$ solution $\left(1 \mathrm{~mol} \cdot \mathrm{L}^{-1}\right)$ at $\mathrm{pH} 8$ and $2 \mathrm{~h}$ by $15 \mathrm{~mL}$ Milli-Q water. And these extraction solutions were gathered together as one extraction. Step 2: The residue of sub-sample was extracted $2 \mathrm{~h}$ by $15 \mathrm{~mL}$ acetate buffer solution at $\mathrm{pH} 4$ ( $1 \mathrm{~mol} \cdot \mathrm{L}^{-1} \mathrm{CH}_{3} \mathrm{COONa}$ buffered to $\mathrm{pH} 4$ with acetate acid), then extracted 1 h by $15 \mathrm{~mL} \mathrm{MgCl}_{2}$ solution $\left(1 \mathrm{~mol} \cdot \mathrm{L}^{-1}\right)$ at $\mathrm{pH} 8$ twice and $1 \mathrm{~h}$ by $15 \mathrm{~mL}$ Milli-Q water. And these extraction solutions were gathered together as one extraction. Step 3: The residue of sub-sample of step 2 was extracted $16 \mathrm{~h}$ by $19.5 \mathrm{~mL}$ $\mathrm{HCl}$ solution $\left(1 \mathrm{~mol} \cdot \mathrm{L}^{-1}\right)$. Step 4 : The residue of sub-sample of step 3 was ashed $2 \mathrm{~h}$ at $550^{\circ} \mathrm{C}$ and then extracted $24 \mathrm{~h}$ by $19.5 \mathrm{~mL} \mathrm{HCl}$ solution $\left(1 \mathrm{~mol} \cdot \mathrm{L}^{-1}\right)$. After finished entire four steps, the phosphorus concentrations were measured by nutrient analyzer. The forms of $\mathrm{P}$ in each step were defined as Fe-bound P (including exchangeable P, Fe-P), Ca-bound P (Ca-P), debris P (De-P) and organic P (OP), respectively. The sum of these four $\mathrm{P}$ forms was total $\mathrm{P}(\mathrm{TP})$. TP concentration of soil standard GBW07314 was $20.11 \pm 0.33 \mu \mathrm{mol} / \mathrm{g}(\mathrm{n}=7)$, the standard value was $20.85 \pm 1.97 \mu \mathrm{mol} / \mathrm{g}$ and the recovery was $97 \%$. The measured precisions of Fe-P, Ca-P, De-P, OP and TP in soil standard were $2.4 \%$, $1.8 \%, 0.95 \%, 4.7 \%$ and $1.3 \%$, respectively.

\subsection{P Solubility}

$\mathrm{P}$ solubility ( $\mathrm{s}$ ) was calculated as $\mathrm{s}=\frac{c_{\mathrm{t}}}{c_{T P}}$, where $\mathrm{c}_{\mathrm{t}}$ was the accumulated dissolved $\mathrm{P}$ concentration at any time $\mathrm{t}$ for high time-resolution dissolution experiment and $\mathrm{c}_{\mathrm{TP}}$ was the total $\mathrm{P}$ concentration measured by SEDEX Method; specifically, Milli-Q water-soluble P solubility was presented as $\mathrm{s}=\frac{c_{75}}{c_{T P}}$,

185 aged seawater-soluble $\mathrm{P}$ solubility was $\mathrm{s}=\frac{c_{45}}{c_{T P}}$, Milli-Q acid-soluble and aged seawater acid-soluble $\mathrm{P}$ 
solubility were $\mathrm{s}=\frac{c_{112.5}}{c_{T P}}$. These calculations were under the assumption that dissolved inorganic $\mathrm{P}$ in weak basic condition ( $\mathrm{pH}$ 7.8) could leach in weak acidic condition (pH 5.5) and dissolved inorganic $\mathrm{P}$ in weak acidic condition could leach in strong acidic condition ( $\mathrm{pH} 2.0)$.

\subsection{Modeling of Dissolution Curves}

Modeling of dissolution curves for high time-resolution dissolution experiments were conducted as follows: when nutrient concentrations in leachates were exponential decreasing, accumulated dissolution curves were mathematically expressed as uniform equations that based on Avrami Model (Avram, 1939), which were $c_{t}=c_{e} *\left(1-e^{-k t^{n}}\right) t \leq t_{e}$ and $c_{t}=c_{e} t>t_{e}$ (Equations 1), where $t$ was an arbitrary time, $t_{e}$ was the time reached dissolution equilibrium, $c_{t}$ was the accumulated concentration at time $\mathrm{t}, \mathrm{c}_{\mathrm{e}}$ was the accumulated concentration at dissolution equilibrium, $\mathrm{k}$ was the dissolution rate constant and $\mathrm{n}$ was the order of reaction and when nutrient concentrations in the leachates were slightly agitated with time, the cumulative dissolution curve based on the zero-order kinetic model were simply expressed as $\mathrm{c}_{\mathrm{t}}=k * t$ (Equation 2), where $\mathrm{t}$ was an arbitrary time, $\mathrm{k}$ was the dissolution rate constant and $c_{t}$ was the accumulated concentration at time t. Accordingly, aerosol dissolution rate (r) were described as $\mathrm{r}=\mathrm{c}_{\mathrm{e}} * \mathrm{k} * \mathrm{n} * \mathrm{e}^{-\mathrm{kt}} * t^{(n-1)}$ for non-liner accumulated dissolution curves and $\mathrm{r}=\mathrm{k}$ for liner accumulated dissolution curves.

\section{Results}

\subsection{Aerosol Nutrient Concentrations and Water-/Acid-soluble Ratios}

Milli-Q water-soluble nutrient concentrations for ultrasound extractions showed a large range, with 205 arithmetic mean values of $154 \pm 91.6 \mathrm{nmol} \cdot \mathrm{m}^{-3}$ for $\mathrm{NH}_{4}{ }^{+}, 135 \pm 91.3 \mathrm{nmol} \cdot \mathrm{m}^{-3}$ for $\mathrm{NO}_{3}^{-}, 0.51 \pm 0.30$ $\mathrm{nmol} \cdot \mathrm{m}^{-3}$ for $\mathrm{PO}_{4}{ }^{3-}$ and $0.54 \pm 0.36 \mathrm{nmol} \cdot \mathrm{m}^{-3}$ for $\mathrm{SiO}_{3}{ }^{2-}$, respectively. Milli-Q acid-soluble $\mathrm{NH}_{4}{ }^{+}, \mathrm{NO}_{3}{ }^{-}$ 
and $\mathrm{PO}_{4}{ }^{3-}$ concentrations for ultrasound extractions also showed a large range, with arithmetic mean values of $189 \pm 115 \mathrm{nmol} \cdot \mathrm{m}^{-3}$ for $\mathrm{NH}_{4}^{+}, 135 \pm 81 \mathrm{nmol} \cdot \mathrm{m}^{-3}$ for $\mathrm{NO}_{3}{ }^{-}$and $1.3 \pm 1.1 \mathrm{nmol} \cdot \mathrm{m}^{-3}$ for $\mathrm{PO}_{4}{ }^{3-}$, respectively. Acid-/water-soluble ratios were 1.1 for $\mathrm{NH}_{4}{ }^{+}$and 0.9 for $\mathrm{NO}_{3}{ }^{-}$and 2.2 for $\mathrm{PO}_{4}{ }^{3-}$ (Fig. 4). In the high time-resolution dissolution experiments, varied Milli-Q/aged water-soluble nutrient concentrations were lower than Milli-Q/aged acid-soluble nutrient concentrations (Table S3). Acid-/water-soluble ratios were 1.0 for $\mathrm{NH}_{4}{ }^{+}$and 1.0 for $\mathrm{NO}_{3}{ }^{-}, 2.6$ for $\mathrm{PO}_{4}{ }^{3-}$ and 2.5 for $\mathrm{SiO}_{3}{ }^{2-}$.

In both measurements, concentrations of acid-soluble nitrogen species were 0.9-1.1 times higher than water-soluble concentrations and concentrations of acid-soluble $\mathrm{PO}_{4}{ }^{3-}$ were 2.2-2.6 times higher than water-soluble $\mathrm{PO}_{4}{ }^{3-}$ concentrations regardless of different leaching liquid, indicating that it was difficult for aerosols to release more inorganic nitrogen even if the dissolution time increased or the acidity increased, but the acid could increase P solubility.

\subsection{P Forms}

Aerosol TP concentrations varied from 5.71 to $20.47 \mu \mathrm{mol} \cdot \mathrm{g}^{-1}$ and the highest TP concentration was found in spr-NW aerosol (Fig. 3). Concentrations of total inorganic P (Fe-P, Ca-P and De-P) represented $90-100 \%$ of TP were varied between 5.6 and $19.0 \mu \mathrm{mol} \cdot \mathrm{g}^{-1}$. Fe-P concentrations were 4.27-7.02 $\mu \mathrm{mol} \cdot \mathrm{g}^{-1}$, Ca-P concentrations were $1.31-11.34 \mu \mathrm{mol} \cdot \mathrm{g}^{-1}$ and De-P concentrations were $0-0.80 \mu \mathrm{mol} \cdot \mathrm{g}^{-1}$. The SEDEX extractions revealed that Ca-P was the dominant $\mathrm{P}$ forms in spr-NW aerosol, whereas Fe-P was the dominant $\mathrm{P}$ forms in other aerosols. In Asian sand-dust, percentage of Ca-P of TP ranged 48\%-94\% and that of Fe-P ranged $0.12 \%-14 \%$ (Yang, 2012). Spr-NW aerosol had typical composition of Asian sand-dust, containing 55\% Ca-P but 33\% Fe-P. Change in Fe-P proportion was possibly aroused by newly formed iron particles during cloud processing (Shi et al., 2009) and evinced that aerosol mightily had been experienced atmospheric acidification.

\subsection{Depictions and Equations for Dissolution Curves}

Aerosol $\mathrm{NH}_{4}{ }^{+}$and $\mathrm{NO}_{3}{ }^{-}$had similar dissolution process, $\mathrm{PO}_{4}{ }^{3-}$ and $\mathrm{SiO}_{3}{ }^{2-}$ had similar dissolution 
process (Fig. $5 \&$ Fig. S2). Raw $\mathrm{NO}_{3}{ }^{-}$and $\mathrm{NH}_{4}{ }^{+}$concentrations were rapidly reduced from high initial concentrations during 0-6/7.5 min and followed by no longer release except for win-NW2 aerosol. However, $\mathrm{NH}_{4}{ }^{+}$and $\mathrm{NO}_{3}{ }^{-}$dissolution of win-NW2 aerosol during 45-75 min and 75-112.5 min were small, which were less important because $95 \% \pm 5 \%$ of total accumulated $\mathrm{NH}_{4}^{+}$or $\mathrm{NO}_{3}^{-}$had been released at $\mathrm{pH}$ 7.8. Hence, accumulated $\mathrm{NH}_{4}{ }^{+}$and $\mathrm{NO}_{3}{ }^{-}$dissolution curves could be described as Equations 1. Raw $\mathrm{PO}_{4}{ }^{3-}$ and $\mathrm{SiO}_{3}{ }^{2-}$ concentrations were rapidly reduced from high initial concentrations to near-zero within $6 \mathrm{~min}$, rapidly soared to the second high concentrations after $75 \mathrm{~min}$ and then reduced to varying degrees. Correspondingly, accumulated $\mathrm{PO}_{4}{ }^{3-}$ and $\mathrm{SiO}_{3}{ }^{2-}$ concentrations at $\mathrm{pH} 7.8$ accounted for $33 \pm 14 \%$ and $34 \pm 21 \%$ of the total accumulated $\mathrm{PO}_{4}^{3-}$ and $\mathrm{SiO}_{3}{ }^{2-}$ concentrations, respectively. After the first $\mathrm{pH}$ change, $\mathrm{PO}_{4}{ }^{3-}$ and $\mathrm{SiO}_{3}{ }^{2-}$ dissolution of aerosols were overall at a slow rate. At pH 5.5, accumulated $\mathrm{PO}_{4}{ }^{3-}$ and $\mathrm{SiO}_{3}{ }^{2-}$ concentrations accounted for $6 \pm 3 \%$ and $13 \pm 14 \%$ of the total accumulated $\mathrm{PO}_{4}{ }^{3-}$ and $\mathrm{SiO}_{3}{ }^{2-}$ concentrations, respectively. After the second $\mathrm{pH}$ change, $\mathrm{PO}_{4}{ }^{3-}$ and $\mathrm{SiO}_{3}{ }^{2-}$ dissolution of aerosols were from quick to slow until dissolution curves reached a plateau. At $\mathrm{pH}$ 2.0, accumulated $\mathrm{PO}_{4}{ }^{3-}$ and $\mathrm{SiO}_{3}{ }^{2-}$ concentrations accounted for $61 \pm 16 \%$ and $52 \pm 30 \%$ of the total accumulated $\mathrm{PO}_{4}{ }^{3-}$ and $\mathrm{SiO}_{3}{ }^{2-}$ concentrations. Therefore, aerosol accumulated $\mathrm{PO}_{4}{ }^{3-}$ and $\mathrm{SiO}_{3}{ }^{2-}$ dissolution curves could be depicted as three stages classified according to different dissolution processes at corresponding $\mathrm{pH}$, so accumulated $\mathrm{PO}_{4}{ }^{3-}$ and $\mathrm{SiO}_{3}{ }^{2-}$ dissolution curves could be described as combinations of Equation 1 and Equation 2, of which Equation 1 was used to fit in curves at pH 7.8 and 2.0 and Equation 2 was used to fit in curves at $\mathrm{pH}$ 5.5.

Equation parameters for high time-resolution dissolution curves were given in Table 1 and Table 2. The dissolution rate constant $(\mathrm{k})$ of $\mathrm{NH}_{4}{ }^{+}$and $\mathrm{NO}_{3}{ }^{-}$exceeded $\mathrm{k}$ of $\mathrm{PO}_{4}{ }^{3-}$ and $\mathrm{SiO}_{4}{ }^{3-}$, reflecting that aerosol $\mathrm{N}$ species dissolution was easier and faster. The values of $\mathrm{k}$ were ranged $0.0047-0.90 \mathrm{~min}^{-1}$ for $\mathrm{PO}_{4}^{3-}$ and $0.0005-0.33 \mathrm{~min}^{-1}$ for $\mathrm{SiO}_{3}{ }^{2-}$ in this study and ranged $0.13-0.80 \mathrm{~min}^{-1}$ for $\mathrm{PO}_{4}{ }^{3-}$ and $0.10-0.91$ $\mathrm{min}^{-1}$ for $\mathrm{SiO}_{3}{ }^{2-}$ in reported study (Wang et al., 2017). Similar k ranges for $\mathrm{PO}_{4}{ }^{3-}$ and $\mathrm{SiO}_{3}{ }^{2-}$ confirmed that aerosol $\mathrm{P}$ and $\mathrm{Si}$ dissolution were harder and slower than aerosol $\mathrm{N}$ species. However, mean $\mathrm{k}$ 
values of Qianliyan aerosols were lower than mean k values of Qingdao aerosols. The experimental apparent reaction order (n) was expressed dissolution reaction mechanism that is the relationship between the dissolution reaction rates and nutrient concentrations. Mean $\mathrm{n}$ values were $0.72 \pm 0.42$ for $\mathrm{NH}_{4}{ }^{+}, 1.01 \pm 0.44$ for $\mathrm{NO}_{3}{ }^{-}, 0.80 \pm 0.26$ for $\mathrm{PO}_{4}^{3-}$, and $0.96 \pm 0.39$ for $\mathrm{SiO}_{3}{ }^{2-}$, respectively. Therefore, the aerosol inorganic N, P and Si dissolution were quasi-first-order reactions. This was in consistence with reported $\mathrm{n}$ values of $\mathrm{P}$ and $\mathrm{Si}$ dissolution equations (Truesdale et al. 2005; Wang et al. 2017). Furthermore, P dissolution in aged seawater needed 37.5-42 min for equilibrium, whereas $\mathrm{P}$ dissolution in Milli-Q water needed within 10-15 min for equilibrium (Wang et. al., 2017), which meant aerosol P dissolution were different in atmosphere and in sea-water. Additionally, accumulated $\mathrm{P} / \mathrm{Si}$ molar ratio curves (Fig. 6) that tended to be fixed over time were indicated the mix release of $\mathrm{P}$ and $\mathrm{Si}$ in aerosols that may caused by non-stoichiometric and/or stoichiometric dissolution of apatites and silicates.

\subsection{P solubility}

Phosphorus solubility varied within time and tended to stabilize in a short time (Fig. 7). Overall, the aged seawater-soluble P solubility of SW aerosol was greater than that of all NW aerosols and the aged seawater acid-soluble P solubility of SW aerosol was the second largest solubility of all aerosols, which revealed that $\mathrm{P}$ in SW aerosols may be attacked by acidic gas that released from the source and during air-masses long-distance transport and part of acid-soluble $\mathrm{P}$ was converted into seawater-soluble phosphorus. For same NW aerosols, aged seawater-soluble P solubility were 7\%, 9\%, 27\% and $16 \pm 3 \%$ in spring, summer, autumn and winter, respectively; aged seawater acid-soluble P solubility were $41 \%$, $18 \%, 54 \%$ and $69 \pm 35 \%$ in spring, summer, autumn and winter, respectively. The difference that seawater acid-soluble P solubility minus aged seawater-soluble P solubility was indicated the maximum dissolved P potential in seawater.

Milli-Q water-soluble P solubility of spr-NW and win-NW2 aerosols were both $8 \%$ and Milli-Q acid-soluble P solubility aerosol of them were $36 \%$ and $17 \%$, respectively. Compared to P solubility in 
Milli-Q water for Qianliyan aerosols, Milli-Q water-soluble P solubility of spr-NW and win-NW aerosols were $9 \%$ and $22 \%$, respectively, and Milli-Q acid-soluble P solubility aerosol of them were 95\% and 65\%, respectively for Qingdao (a city adjacent to the Yellow sea) aerosols (Wang et. al., 2017). For same source aerosols, Milli-Q acid-soluble $\mathrm{P}$ solubility that represented the maximum potential ability of acid to modify aerosol $\mathrm{P}$ during atmosphere transport was higher in spring than in winter though Milli-Q water-soluble P solubility was similar in spring and winter.

\section{Discussion}

\subsection{Relevance of Aerosol Inorganic Components and Dissolution Patterns}

The dissolution patterns were closely related to aerosol inorganic components because components determined structures and structures determined their natures of dissolution. Dissolution can be induced by concentration diffusion and/or ions attraction effect, of which ions attraction effect referred to aerosol chemical reactions with hydroxyls $\left(\mathrm{OH}^{-}\right)$, water molecules $\left(\mathrm{H}_{2} \mathrm{O}\right)$, protons $\left(\mathrm{H}^{+}\right)$and/or organic ligands under corresponding basic, neutral and acid solutions. In high time-resolution dissolution experiments, the leachates were subsequently moved out of the reaction system in time series, so dissolution at each time interval was unsaturated. Considered that an average of $98 \%$ (96-100\%) of the cumulative dissolved $\mathrm{NH}_{4}{ }^{+}$and $\mathrm{NO}_{3}{ }^{-}$in aerosols was dissolved at $\mathrm{pH} 7.8$, the dissolution of aerosol $\mathrm{N}$ species was mainly induced by existing nutrient concentration differences and the dissolution of aerosol $\mathrm{N}$ species would not stop until soluble components had been used up. The main deliquescent $\mathrm{NO}_{3}{ }^{-}$and $\mathrm{NH}_{4}{ }^{+}$components in aerosols, such as $\mathrm{NH}_{4} \mathrm{Cl}, \mathrm{Ca}\left(\mathrm{NO}_{3}\right)_{2}, \mathrm{KNO}_{3}, \mathrm{Mg}\left(\mathrm{NO}_{3}\right)_{2}, \mathrm{NaNO}_{3}, \mathrm{NH}_{4} \mathrm{NO}_{3}$, $\left(\mathrm{NH}_{4}\right)_{2} \mathrm{SO}_{4}$ and $\mathrm{NH}_{4} \mathrm{HSO}_{4}$, were highly water-soluble (Pakkanen et al., 1996; Foltescu et al., 1996;

Seinfeld and Pandis, 1998; Moise et al., 2002) and these bio-available inorganic salts decomposed immediately and rapidly into ions forms in contact with liquids (Lide 2007). However, considered that averagely $33 \%$ (15-53\%) of the cumulative dissolved $\mathrm{PO}_{4}^{3-}$ and $34 \%(5 \%-69 \%)$ of the cumulative dissolved $\mathrm{SiO}_{3}{ }^{2-}$ in aerosols were dissolved at $\mathrm{pH}$ 7.8, the dissolution of aerosol $\mathrm{P}$ and $\mathrm{Si}$ species were 
induced by both nutrient concentration differences and chemical reactions that caused by ion attractions, which meant more complex dissolution patterns than $\mathrm{N}$ species.

Typically $90 \%$ water-soluble components of aerosols over the Yellow sea were $\mathrm{NH}_{4}{ }^{+}, \mathrm{NO}_{3}{ }^{-}, \mathrm{SO}_{4}{ }^{2-}$ and $\mathrm{Cl}^{-}$(Yang \& Xiu, 2009; Wang et al., 2018). Assumed that $\mathrm{NH}_{4} \mathrm{Cl}, \mathrm{NH}_{4} \mathrm{NO}_{3},\left(\mathrm{NH}_{4}\right)_{2} \mathrm{SO}_{4}$ were major sources of $\mathrm{NH}_{4}{ }^{+}$and $\mathrm{NO}_{3}{ }^{-}$ions and dissolved in stable stoichiometric relation, $\mathrm{NH}_{4}{ }^{+} / \mathrm{NO}_{3}{ }^{-}$ratio must be larger than 1. If considered the aging process in the transport pathway of aerosol particles, there existed a tendency to form complex salt $\left(\left(\mathrm{NH}_{4} \mathrm{NO}_{3}\right)_{3} \cdot\left(\mathrm{NH}_{4}\right)_{2} \mathrm{SO}_{4}\right.$ and $\left.\left(\mathrm{NH}_{4} \mathrm{NO}_{3}\right)_{2} \cdot\left(\mathrm{NH}_{4}\right)_{2} \mathrm{SO}_{4}\right)$ (Schlenker et al., 2003; Saathoff et al., 2003) except for gas-particle transformation forms $\left(\left(\mathrm{NH}_{4}\right)_{2} \mathrm{SO}_{4}\right.$ and $\left.\mathrm{NH}_{4} \mathrm{NO}_{3}\right)$. In a more complex situation, $\mathrm{NH}_{4}{ }^{+} / \mathrm{NO}_{3}{ }^{-}$ratios were also larger than 1 under assumption that $\mathrm{NH}_{4} \mathrm{Cl}$, $\mathrm{NH}_{4} \mathrm{NO}_{3}$, $\left(\mathrm{NH}_{4}\right)_{2} \mathrm{SO}_{4},\left(\mathrm{NH}_{4} \mathrm{NO}_{3}\right)_{3} \cdot\left(\mathrm{NH}_{4}\right)_{2} \mathrm{SO}_{4}$ and $\left(\mathrm{NH}_{4} \mathrm{NO}_{3}\right)_{2} \cdot\left(\mathrm{NH}_{4}\right)_{2} \mathrm{SO}_{4}$ were primarily providers of $\mathrm{NH}_{4}{ }^{+}$and $\mathrm{NO}_{3}{ }^{-}$. However, cations such as $\mathrm{Ca}^{2+}$ and $\mathrm{Na}^{+}$were also composed of aerosols (Suzuki et al., 315 2010; Zheng et al., 2011). Since spr-NW aerosol had highest Ca-P/TP (55\%) and win-NW2 aerosol had lowest Ca-P/TP (20\%), these two aerosols were selected for testing whether $\mathrm{NH}_{4}{ }^{+} / \mathrm{NO}_{3}{ }^{-}$ratio could be an indicator to aerosol major components under the assumption that $\mathrm{Ca}$ were mostly combined with $\mathrm{P}$ since apatite minerals were precursors in $\mathrm{P}$ aerosols. Accumulated $\mathrm{NH}_{4}{ }^{+} / \mathrm{NO}_{3}{ }^{-}$ratios (Fig. 8) for leachates from start till $\mathrm{NH}_{4}{ }^{+} / \mathrm{NO}_{3}{ }^{-}$ratio curve reached the plateau were $0.9 \pm 0.1$ and $2.6 \pm 0.3$ on average for spr-NW and win-NW2 aerosols in aged seawater and $0.4 \pm 0.01$ and $1.5 \pm 0.1$ for spr-NW and win-NW2 aerosols in Milli-Q water. Accumulated $\mathrm{NH}_{4}{ }^{+} / \mathrm{NO}_{3}{ }^{-}$ratio curves may indicated that main components of win-NW2 sample were $\mathrm{NH}_{4} \mathrm{Cl}, \mathrm{NH}_{4} \mathrm{NO}_{3},\left(\mathrm{NH}_{4}\right)_{2} \mathrm{SO}_{4}$ and/or their complex salts, while contents of other inorganic salts containing contained $\mathrm{NO}_{3}{ }^{-}$in the spr-NW aerosol such as $\mathrm{Ca}\left(\mathrm{NO}_{3}\right)_{2}$ and $\mathrm{NaNO}_{3}$ that produced from the gas-particle conversions were not negligible, which was in consist with reported result that spr-NW aerosol carried terrigenous particles and/or loess soils (Liu et al., 2002). In summary, $\mathrm{NH}_{4}{ }^{+} / \mathrm{NO}_{3}{ }^{-}$ratio could be a rough indicator to evaluate crustal element such as $\mathrm{Ca}$ as major components.

Aerosol $\mathrm{P}$ and $\mathrm{Si}$ species were mainly composed of soil-derived crystalline minerals, artificial 
fertilizer particles and their aged amorphous forms (Yuan et al., 2018) because they can not be formed by gas-particle transformation. In addition, physical and/or chemical changes of aerosols could occur via atmospheric transport paths. Therefore, superficial exchangeable P and Si species (aged amorphous forms) that were primarily affected by surface diffusion rates may be the first components released into solution (Tang et al., 2003; Wang et al., 2017). After superficial exchangeable P and Si had been used up within $45 \mathrm{~min}$, crystalline particles started to collapse resulting from $\mathrm{H}^{+}$ion attack effect in exchange for P and Si from solids (Guidry and Mackenzie, 2003). At $\mathrm{pH}$ 5.5, $\mathrm{H}^{+}$concentrations were not strong enough to easily drag P and Si out of their lattice. Besides, leaching system was entirely not acid- or alkline-buffered, so if solid $\mathrm{CaCO}_{3}$ had not been consumed up, $\mathrm{H}^{+}$would first attacked $\mathrm{CaCO}_{3}$ before attacked P-containing and Si-containing particles, resulting in the lesser release of $\mathrm{P}$ and $\mathrm{Si}$ into solution. As shown in dissolution equations, $\mathrm{k}_{2}$ of $\mathrm{P}$ and $\mathrm{Si}$ in aerosol were small constants, which supported that exchangeable $\mathrm{P}$ and Si had already dissolved; and $\mathrm{n}$ was 0 , which demonstrated that dissolution reactions were independence from reactant concentrations. At $\mathrm{pH} 2.0, \mathrm{H}^{+}$concentrations were sufficient to break up crystalline structures of aerosol particles and liberate them into liquid phase and no more $\mathrm{P}$ and Si release in aerosols would occur once soil-derived crystalline minerals and anthropogenic fertilizers were depleted by $\mathrm{H}^{+}$in leaching liquids.

Average $\mathrm{k}$ values of P and Si dissolution for Qianliyan aerosols were $0.25 \pm 0.08$ and $0.22 \pm 0.06$, respectively, and average $\mathrm{k}$ values of $\mathrm{P}$ and Si dissolution for Qingdao aerosols were $0.10 \pm 0.11$ and $0.16 \pm 0.07$, respectively. Comparison showed that dissolution rate constants were close, however, dissolution rates for Qianliyan and Qingdao aerosols were varied. Also, water-soluble/acid-soluble P and Si ratios in Qingdao aerosols showed apparent discrepancy (Wang et al., 2017), but they showed a rather constant values in Qianliyan aerosols (Fig. 4). When considering that dissolution reactions of $\mathrm{P}$ and $\mathrm{Si}$ were quasi-first-order and the slowest reactions controlled reaction rates, the least soluble P-containing and Si-containing components in Qianliyan and Qingdao aerosols were different. Alternations of aerosol P-containing and Si-containing precursors surface properties during atmospheric 
mass transport, such as hygroscopicity and crystal lattice deformation (rough surface) that could possibly make the size changes of P-containing and Si-containing particles were resulted in variations that water-soluble $\mathrm{P}$ and $\mathrm{Si}$ needed around $40 \mathrm{~min}$ to reach dissolution equilibrium for Qianliyan aerosols, but around $15 \mathrm{~min}$ for Qingdao aerosols.

Natural apatites and silicates minerals were major precursors of aerosol particles. Generally, apatites included $\mathrm{Ca}_{5}\left(\mathrm{PO}_{4}\right)_{3} \mathrm{~F}, \mathrm{Ca}_{5}\left(\mathrm{PO}_{4}\right)_{3} \mathrm{OH}, \mathrm{Ca}_{5}\left(\mathrm{PO}_{4}\right)_{3} \mathrm{Cl}$ and silicates included quartz, montmorillonite, illite and kaolinite etc. Laboratory dissolution rate experiments on minerals indicated that silicates dissolution rates were often lower than that of apatites (Lerman \& Wu, 2008). Mineral dissolution rates were often normalized by total surface area, so mean dissolution rate $\left(\mathrm{r}_{\mathrm{a}}\right)$ was defined as $\mathrm{r}_{\mathrm{ai}}=\frac{\mathrm{c}_{\mathrm{e}}}{\mathrm{c}_{T S P} * \mathrm{~s} * \mathrm{t}_{\mathrm{e}}}$, where i was the stage 1, 2 and 3 corresponding to scenarios at $\mathrm{pH} 7.8,5.5$ and 2.0, respectively, $\mathrm{s}$ was aerosol surface area, $\mathrm{c}_{\mathrm{e}}$ was the accumulated concentrations when dissolution reached equation, $\mathrm{c}_{\mathrm{TSP}}$ was aerosol TSP mass concentration and $t_{e}$ was time when dissolution reached equation. It assumed that aerosol surface area (s) was $4 \mathrm{~m}^{2} \cdot \mathrm{g}^{-1}$ (Guo et al., 2017) and $\mathrm{r}_{\text {ai }}$ could compare with these mineral dissolution rates of aerosol precursors after normalization. SW aerosol had higher $r_{a}$ than other NW aerosols (Table S4) indicated that mineralogical compositions were source-induced different. The largest $r_{a 1}$ of P-containing aerosols was $1562 \cdot 10^{-12} \mathrm{molm}^{-2} \mathrm{~s}^{-1}$, which was much lower than that of carbonated hydroxyapatite $\left(52000 \cdot 10^{-12} \mathrm{~mol} \cdot \mathrm{m}^{-2} \mathrm{~s}^{-1}\right.$; Tang, et al., 2003) and was close to that of igneous fluorapatite $\left(1830 \cdot 10^{-12}\right.$ $\mathrm{mol} \cdot \mathrm{m}^{-2} \mathrm{~s}^{-1}$; Valsami-Jones, et al., 1998); the lowest $\mathrm{r}_{a 1}$ was $60 \cdot 10^{-12} \mathrm{~mol} \cdot \mathrm{m}^{-2} \mathrm{~s}^{-1}$, which was much higher than that of sedimentary carbonate fluorapatite $\left(5.01 \cdot 10^{-12} \mathrm{~mol} \cdot \mathrm{m}^{-2} \mathrm{~s}^{-1}\right.$; Guidry \& Mackenzie, 2003) and was close to that of pure hydroxyapatite $\left(53.3 \cdot 10^{-12} \mathrm{~mol} \cdot \mathrm{m}^{-2} \mathrm{~s}^{-1}\right.$; Valsami-Jones, et al., 1998); the mean $\mathrm{r}_{\mathrm{al}}$ was $443 \cdot 10^{-12} \mathrm{~mol} \cdot \mathrm{m}^{-2} \mathrm{~s}^{-1}$, which was slight higher than that of natural fluorapatite $\left(380 \cdot 10^{-12} \mathrm{~mol} \cdot \mathrm{m}^{-2} \mathrm{~s}^{-1}\right.$; 375 Guidry \& Mackenzie, 2003). Aerosol mean $r_{a 1}$ was close to dissolution rate of fluorapatite mineral, indicating that fluorapatite was possibly main inorganic composition in all aerosols. Aerosol mean $r_{a 1}$ for $\mathrm{Si}$ were much higher than mineral dissolution rates of most silicates, while the largest $\mathrm{r}_{\mathrm{a} 1}$ of 
Si-containing aerosol particles was $3916 \cdot 10^{-12} \mathrm{~mol} \cdot \mathrm{m}^{-2} \mathrm{~s}^{-1}$, the lowest $\mathrm{r}_{a 1}$ was $23 \cdot 10^{-12} \mathrm{~mol} \cdot \mathrm{m}^{-2} \mathrm{~s}^{-1}$ and the mean $\mathrm{r}_{\mathrm{a} 1}$ was $838 \cdot 10^{-12} \mathrm{~mol} \cdot \mathrm{m}^{-2} \mathrm{~s}^{-1}$. Also, summer and winter aerosols had lower $\mathrm{r}_{\mathrm{a}}$ than other seasons aerosols. Laboratory dissolution rates of pure quartz was $15 \cdot 10^{-12} \mathrm{~mol} \cdot \mathrm{m}^{-2} \mathrm{~s}^{-1}$, major mineral clay silicates, such as kaolinite, montmorillonite and illite, were $0.012 \cdot 10^{-12}, 9.8 \cdot 10^{-12}$ and $0.011 \cdot 10^{-12}$ $\mathrm{mol} \cdot \mathrm{m}^{-2} \mathrm{~s}^{-1}$, respectively (Huertas et al., 1999; Bauer and Berger ,1998; Köhler et al., 2003). These low dissolution rate species could not support higher aerosol $r_{a 1}$ since mixed dissolution rates were controlled by the lowest reaction reactions. Dissolution rates of $\mathrm{Ca}$ - and $\mathrm{Mg}$-containing silicates, such as enstatite, diopside, olivine ranged from $10-316.2 \cdot 10^{-12} \mathrm{~mol} \cdot \mathrm{m}^{-2} \mathrm{~s}^{-1}$ (Oelkerset al., 2001; Schott et al., 1981; Lasaga, 1988). These slight higher dissolution rate species could be possibly considered as majority Si-containing aerosol species in summer and winter. However, the highest dissolution rate species, pure $\mathrm{CaAl}_{2} \mathrm{Si}_{2} \mathrm{O}_{8}$ and anorthite were $10000 \cdot 10^{-12}$ and $2820 \cdot 10^{-12} \mathrm{~mol} \cdot \mathrm{m}^{-2} \mathrm{~s}^{-1}$ (Fleer, 1982; Blum and Stillings, 1995), of which anorthite could be considered as majority Si-containing aerosol species in spring and autumn. Despite of different mineralogical compositions, dissolution rate discrepancies between aerosols and their natural precursors may be explained by atmospheric radial or acidified aging process (Mashburn, 2006; Cuadros et al., 2015). Natural minerals acted as an important reactive surface that providing a heterogeneous sink for acidic gas species, dramatically changed the morphology of airborne particles, resulting in expected greater dissolution rates of aerosols. Given that carbonates dissolution rates were incredibly 4-6 orders of magnitude higher than dissolution rates of silicates, carbonated hydroxyapatite dissolution rate was 1-4 orders of magnitude higher than other apatites, hence, co-dissolution of carbonated species might accelerate the rate of aerosol particles dissolution rates and accumulated dissolution amount.

Refractory element Fe was reported to be synchronously released with easier and earlier dissolution of nitrate salts and other acids (sulphate salts and organic acids) and release of $\mathrm{Fe}$ and nitrate salts in Milli-Q were proportioned because of their tight morphology combination or same source (Hsu et al., $2013)$, but $\mathrm{Ca}$ was preferentially released compared to $\mathrm{P}$ from the mineral structure $\left(\mathrm{Ca}_{5}\left(\mathrm{PO}_{4}\right)_{3} \mathrm{~F}\right.$ and 
$\left.\mathrm{Ca}_{5}\left(\mathrm{PO}_{4}\right)_{3} \mathrm{OH}\right)$ at early dissolution reaction (Guidry and Mackenzie, 2003). Theoretically, Fe-P, Ca-P and De-P all could participate in dissolution process, except for OP. Hence, challenges that distinguishing the typical dissolution parameters of individual $\mathrm{P}$ mineral species were failed to overcome even specify $\mathrm{P}$ morphology forms unless increasing sample numbers or changing the collection mode into single particle aerosol.

\subsection{Control Factors of Phosphorus Dissolution}

Aerosol source, solution $\mathrm{pH}$ and solution ion strength (IS) were three major factors that controlled $\mathrm{P}$ solubility in certain leaching liquids. P solubility were also varied with solvents though it had not been discussed afterward.

Firstly, factor affected P solubility may ascribed to source. Regardless of the temporal and spatial influences, P solubility in SW aerosols were generally larger than NW aerosols, for example, SW aerosol had highest aged seawater-soluble P solubility (39\%) than NW aerosols $(16 \% \pm 11 \%)$ at 415 Qianliyan and SW aerosols had higher Milli-Q water-soluble P solubility $(33 \% \pm 10 \%)$ than NW aerosols $(16 \% \pm 7 \%)$ at Qingdao as well (Wang et. al., 2017). P solubility of source soils may be different in itself for different ability on fixing water-soluble phosphorus. Generally, NW-source soils (such as black soil and loess) were weakly alkaline and SW-source soils (such as red soil) were acidic. If acid had the same mechanism for soil P solubility and aerosol P solubility, P solubility in SW aerosols were surely larger than NW aerosols. However, source-induced variation also inherently included aging processes during airborne mass transport, but the degree of aerosol aging was difficult to quantify. Therefore, future research needs to further divest the intrinsic core of source factor.

Secondly, factor affected P solubility may attributed to acidity. Milli-Q acid-soluble P solubility was three times higher than Milli-Q water-soluble P solubility and aged seawater acid-soluble P solubility was approximately three times higher than aged seawater-soluble P solubility on average (Fig. 7), which highlighted the acidity effect. Laboratory simulated atmospheric acidification treatment caused a 10-40 
times increase of soluble phosphorus amount (Nenes et al., 2011) in Sahara soil dust, however, in our experiment, only 5 times increase of soluble phosphorus amount for spr-NW aerosol that strongly influenced by Asian sand-dust event. This showed variations of acidity effect on different regional aerosols. Spr-NW aerosol that had been acidified in the leaching experiment displayed no effect under slight increase of $\mathrm{H}^{+}\left(10^{5.5} \mathrm{~mol} \cdot \mathrm{L}^{-1}\right)$, but a sharp and solid increase amount of soluble phosphorus under stronger $\mathrm{H}^{+}\left(10^{2.0} \mathrm{~mol} \cdot \mathrm{L}^{-1}\right)$. This implied that particulate $\mathrm{P}$ in aerosol accelerated dissolution when leaching solution reached a given $\mathrm{H}^{+}$concentration. Study on atmospheric acid processing of mineral dust brought up the point that less than $10 \%$ of total phosphorus dissolved when $\mathrm{H}^{+}$ion concentration was under $10^{-4} \mathrm{~mol} \mathrm{H}^{+} / \mathrm{g}$ of dust but when $\mathrm{H}^{+}$ion concentration was higher than $10^{-4} \mathrm{~mol} \mathrm{H}^{+} / \mathrm{g}$ of dust, aerosol particulates consumed $\mathrm{H}^{+}$ions until inorganic form of phosphorus particles exhausted (Stockdale et al., 2016). In our high time-resolution dissolution experiments, hypothesized that the mass of aerosol on subsamples unchanged during the whole processing because only the soluble species removed, $\mathrm{H}^{+}$ion concentration for spr-NW aerosol was $1.8 \cdot 10^{-7} \mathrm{~mol} \mathrm{H}^{+} / \mathrm{g}$ at $\mathrm{pH} 7.8$ and $2.4 \cdot 10^{-5} \mathrm{~mol}$ $\mathrm{H}^{+} / \mathrm{g}$ at $\mathrm{pH}$ 5.5. These $\mathrm{H}^{+}$ion concentrations were below the threshold value. But $\mathrm{H}^{+}$ion concentration that was $9.6 \cdot 10^{-2} \mathrm{~mol} \mathrm{H}^{+} / \mathrm{g}$ at $\mathrm{pH} 2.0$ was exceeded the threshold value. Though particle properties were different between Sahara dust and Asian dust, threshold of $\mathrm{H}^{+}$ion per particle did existed and further dissolution did occur only when acidity surpassed the threshold value. In future, whether Sahara dust and Asian dust shared the same threshold or different threshold should be tested.

Thirdly, factor affected P solubility may be attributed to a small extent to IS. The effect of seawater or salt addition on P solubility were positive because aged seawater acid-soluble P solubility was averagely slightly higher than Milli-Q acid-soluble P solubility. In theory, presence of strong electrolytes $(\mathrm{NaCl}$ and $\mathrm{MgCl}_{2}$ ) in aged sea water strengthened electrostatic interactions (such as desorption) and liberated rather insoluble masses into solution. However, IS-induced effect was smaller than source and $\mathrm{pH}$ effects in high time-resolution dissolution experiment because aged seawater $(\mathrm{IS}=0.7)$ increased $\mathrm{P}$ solubility by a factor of $1-2$, unless adding $\mathrm{NaCl}$ to increase IS to 2 , it was possible to increase $\mathrm{P}$ 
solubility by a factor of 4.3 (Stockdale et al., 2016).

\section{Conclusions}

In this study, we mainly focused on the high time-resolution dissolution experiments, modeled the dissolution curves and probed factors influenced dissolution rates, especially for P solubility. Our modeling of nutrient dissolution curves depicted by Avrami model and/or zero-order kinetics model for high time-resolution dissolution experiments were indicated that reactions of aerosol inorganic $\mathrm{N}, \mathrm{P}$ and Si species short-time dissolution in natural waters were quasi-first-order. Varied dissolution rates were caused by aerosol inorganic components. Discussions of aerosol inorganic components and dissolution patterns revealed their inherent relations that $\mathrm{N}$ species were more likely to immediately and completely dissolve due to fine particles formed by gas-particle transformation, while $\mathrm{P}$ and $\mathrm{Si}$ were tended to dissolve more in low acidity largely because of coarse soil-derived mineral particles. By comparisons of water-soluble and acid soluble nutrient concentrations in dissolution experiments and ultra-sound extractions, ratios of acid-soluble to water-soluble nutrient concentrations were $1.0(0.9-1.1)$ for $\mathrm{NH}_{4}{ }^{+}$ and $\mathrm{NO}_{3}{ }^{-}, 2.4$ (2.1-2.6) for $\mathrm{PO}_{4}{ }^{3-}$ and 2.5 for $\mathrm{SiO}_{3}{ }^{2-}$. In addition, prominent factors influenced $\mathrm{P}$ solubility were source and acidity, while other less important factors that could affected aerosol P solubility were solution ion strength.

\section{Acknowledgements}

This paper is financially supported by the National Research and Development program of China (2016YFA0600902), Aoshan Talents Program Supported by Qingdao National Laboratory for Marine Science and Technology (2015ASTP-OS08), National Science Foundation of China (41521064, 41776087), and the Taishan Scholars Program of Shandong Province. We also sincerely thank the staffs working in the Qianliyan Department of the North China Sea Branch of State Oceanic Administration 475 for their help in sample collection.

\section{References}

Aghnatios, C., Losno, R., \& Dulac, F. (2014). A fine fraction of soil used as an aerosol analogue during the DUNE experiment: Sequential solubility in water, decreasing pH step-by-step. Biogeosciences. https://doi.org/10.5194 
Atmos. Chem. Phys. Discuss., https://doi.org/10.5194/acp-2018-985

Atmospheric

Manuscript under review for journal Atmos. Chem. Phys.

Chemistry

Discussion started: 6 December 2018

(c) Author(s) 2018. CC BY 4.0 License.

and Physics

Discussions

(c) (i)

Anderson, L. D., Faul, K. L., \& Paytan, A. (2010). Phosphorus associations in aerosols: What can they tell us about P bioavailability? Marine Chemistry, 120(1-4), 44-56. https://doi.org/10.1016/j.marchem.2009.04.008

Avrami, M. (1939). Kinetics of Phase Change. I General Theory. The Journal of Chemical Physics. https://doi.org/10.1063/1.1750380

Baker, A. R., French, M., \& Linge, K. L. (2006b). Trends in aerosol nutrient solubility along a west-east transect of the Saharan dust plume. Geophysical Research Letters. https://doi.org/10.1029/2005GL024764

Baker, A. R., Jickells, T. D., Witt, M., \& Linge, K. L. (2006a). Trends in the solubility of iron, aluminium, manganese and phosphorus in aerosol collected over the Atlantic Ocean. Marine Chemistry. https://doi.org/10.1016/j.marchem.2005.06.004

Bauer, A., \& Berger, G. (1998). Kaolinite and smectite dissolution rate in high molar $\mathrm{KOH}$ solutions at $35^{\circ} \mathrm{C}$ and $80^{\circ} \mathrm{C}$. Applied Geochemistry. https://doi.org/10.1016/ S0883-2927(98)00018-3

Blum, A. E., Stillings, L. L., \& Ribbe, P. H. (1995). Feldspar dissolution kinetics. Chemical Weathering Rates of Silicate Minerals, 31, 291-351.

Blum, A., \& Lasaga, A. (1988). Role of surface speciation in the low-temperature dissolution of minerals. Nature, 331(6155), 431-433. https://doi.org/10.1038/331431a0

Chen, B., Hu, K., Jie, D. M., Kitagawa, H., \& Li, F. L. (2006). Seasonal changes of alkaline dust aerosol and its climate influencing factors in western Songnen plain, north-east china. Acta Scientiae Circumstantiae, 26(3), 521-527. (in Chinese version)

Chen, H. Y., Fang, T. H., Preston, M. R., \& Lin, S. (2006). Characterization of phosphorus in the aerosol of a coastal atmosphere: Using a sequential extraction method. Atmospheric Environment. https://doi.org/10.1016/j.atmosenv. $\underline{2005.09 .051}$

Chen, Y., Street, J., \& Paytan, A. (2006). Comparison between pure-water- and seawater-soluble nutrient concentrations of aerosols from the Gulf of Aqaba. Marine Chemistry. https://doi.org/10.1016 j.marchem.2006.02.002

505 China Meteorological Administration. (2011) Sand-dust Weather Almanac. China Meteorological Press. (in Chinese version)

Cornell, S., Randell, A., \& Jickells, T. (1995). Atmospheric inputs of dissolved organic nitrogen to the oceans. Nature. https://doi.org/10.1038/376243a0

Cuadros, J., Diaz-Hernandez, J. L., Sanchez-Navas, A., \& Garcia-Casco, A. (2015). Role of clay minerals in the formation of atmospheric aggregates of Saharan dust. Atmospheric Environment. https://doi.org/10.1016 j.atmosenv.2015.08.077

Dobrynin, M., Murawsky, J., \& She, J. (2009). Dynamics of suspended particulate matter in the Yellow Sea investigated by the ensemble of numerical models and satellite data. Assembly, 11, 7004.

Doney, S. C. (2010). The growing human footprint on coastal and open-Ocean biogeochemistry. Science. https://doi.org/10.1126/science.1185198

Duce, R. A., LaRoche, J., Altieri, K., Arrigo, K. R., Baker, A. R., Capone, D. G., ... Zamora, L. (2008). Impacts of atmospheric anthropogenic nitrogen on the open ocean. Science. https://doi.org/10.1126/science.1150369 
Atmos. Chem. Phys. Discuss., https://doi.org/10.5194/acp-2018-985

Manuscript under review for journal Atmos. Chem. Phys.

Discussion started: 6 December 2018

(c) Author(s) 2018. CC BY 4.0 License.

Eyckmans, K., Zhang, J., De Hoog, J., Joos, P., \& Van Grieken, R. (2001). Leaching of nutrients and trace metals from aerosol samples; a comparison between a re-circulation and an ultrasound system. International Journal of Environmental Analytical Chemistry. https://doi.org/10.1080/03067310108044372

Fleer, V.N. Dissolution kinetics of anorthite ( $\mathrm{CaAl} / \mathrm{sub} 2 / \mathrm{Si} / \mathrm{sub} 2 / \mathrm{O} / \mathrm{sub} 8 /$ ) and synthetic strontium feldspar ( $\mathrm{SrAl} / \mathrm{sub} 2 / \mathrm{Si} / \mathrm{sub} 2 / \mathrm{O} / \mathrm{sub} 8 /$ ) in aqueous solutions at temperatures below 100/sup 0/C: with applications to the geological disposal of radioactive nuclear wastes. United States.

Foltescu, V. L., Selin Lindgren, E., Isakson, J., Öblad, M., Pacyna, J. M., \& Benson, S. (1996). Gas-to-particle conversion of sulphur and nitrogen compounds as studied at marine stations in Northern Europe. Atmospheric Environment. https://doi.org/10.1016/1352 -2310(96)00068-4

Gao, H., Yao, X., \& Guo, Z. (2014). Atmospheric Deposition Connected with Marine Primary Production and Nitrogen Cycle: A Review. Advances in Earth Science. https://doi.org/10.11867/j.issn.1001-8166.2014.12.1325

Guidry, M. W., \& Mackenzie, F. T. (2003). Experimental study of igneous and sedimentary apatite dissolution: Control of $\mathrm{pH}$, distance from equilibrium, and temperature on dissolution rates. Geochimica et Cosmochimica Acta. https://doi.org/10.1016/S0016-7037(03)00265-5

Guieu, C., Dulac, F., Desboeufs, K., Wagener, T., Pulido-Villena, E., Grisoni, J. M., ... Dominici, J. M. (2010). Large clean mesocosms and simulated dust deposition: A new methodology to investigate responses of marine oligotrophic ecosystems to atmospheric inputs. Biogeosciences. https://doi.org/10.5194/bg-7-2765-2010

Guieu, C., Dulac, F., Desboeufs, K., Wagener, T., Pulido-Villena, E., Grisoni, J. M., ... Dominici, J. M. (2010). Large clean mesocosms and simulated dust deposition: A new methodology to investigate responses of marine oligotrophic ecosystems to atmospheric inputs. Biogeosciences, 7(9), 2765-2784. https://doi.org/10.5194 bg-7-2765-2010

Guo Bin, Ren Ailing, Li Liangyu, \& Zhao Wenxia. (2007). Vertical distribution characteristics of inhalable particulate matter in Shijiazhuang in autumn. Journal of Chinese Academy of Sciences, 24(5), 714-719. (in Chinese version)

Harrison, K. G. (2000). Role of increased marine silica input on paleo-pCO $<$ inf $>2</$ inf $>$ levels. Paleoceanography. https://doi.org/10.1029/1999PA000427

Hsu, S. C., Lin, F. J., Liu, T. H., Lin, S. H., Kao, S. J., Tseng, C. M., \& Huang, C. H. (2013). Short time dissolution kinetics of refractory elements $\mathrm{Fe}, \mathrm{Al}$, and $\mathrm{Ti}$ in Asian outflow-impacted marine aerosols and implications. Atmospheric Environment, 79, 93-100. https://doi.org/10.1016/j.atmosenv.2013.06.037

Huang, R., Chen, J., \& Huang, G. (2007). Characteristics and variations of the East Asian monsoon system and its impacts on climate disasters in China. In Advances in Atmospheric Sciences (Vol. 24, pp. 993-1023). https://doi.org/10.1007/s00376-007-0993-x

550 Huerta-Diaz, M. A., Tovar-Sánchez, A., Filippelli, G., Latimer, J., \& Sañudo-Wilhelmy, S. A. (2005). A combined CDB-MAGIC method for the determination of phosphorus associated with sedimentary iron oxyhydroxides. Applied Geochemistry, 20(11), 2108-2115. https://doi.org/10.1016/j.apgeochem.2005.07.009

Huertas, F. J., Chou, L., \& Wollast, R. (1999). Mechanism of kaolinite dissolution at room temperature and pressure Part II: Kinetic study. Geochimica et Cosmochimica Acta, 63(19-20), 3261-3275. https://doi.org/10.1016 
Atmos. Chem. Phys. Discuss., https://doi.org/10.5194/acp-2018-985

Manuscript under review for journal Atmos. Chem. Phys.

Discussion started: 6 December 2018

(c) Author(s) 2018. CC BY 4.0 License.

(c) (i)

Atmospheric

Chemistry

and Physics

Discussions

/S0016-7037(99)00249-5

Kocak, M. (2015). Solubility of Atmospheric Nutrients over the Eastern Mediterranean: Comparison between Pure-Water and Sea-Water, Implications Regarding Marine Production. Turkish Journal of Fisheries and Aquatic Sciences, 15(1), 59-71. https://doi.org/10.4194/1303-2712-v15 107

Köhler, S. J., Dufaud, F., \& Oelkers, E. H. (2003). An experimental study of illite dissolution kinetics as a function of ph from 1.4 to 12.4 and temperature from 5 to $50^{\circ} \mathrm{C}$. Geochimica et Cosmochimica Acta. https://doi.org 110.1016/S0016-7037(03)00163-7

Krishnamurthy, A., Moore, J. K., Mahowald, N., Luo, C., \& Zender, C. S. (2010). Impacts of atmospheric nutrient inputs on marine biogeochemistry. Journal of Geophysical Research, 115(G1), G01006. https://doi.org $\underline{10.1029 / 2009 \mathrm{JG} 001115}$

Lerman, A., \& Wu, L. (2008). Kinetics of global geochemical cycles. In Kinetics of Water-Rock Interaction. https://doi.org/10.1007/978-0-387-73563-4_13

Lide, D. R. (2005). CRC Handbook of Chemistry and Physics, Internet Version. Taylor and Francis Boca Raton FL.

Liu, C. L., Zhang, J., \& Liu, S. M. (2002). Physical and chemical characteristics of materials in different mineral aerosol source regions in China. Environmental Science, 23(4), 28-32. (in Chinese version)

Liu, L.-Y., Wang, J.-Z., Wei, G.-L., Guan, Y.-F., Wong, C. S., \& Zeng, E. Y. (2012). Sediment Records of Polycyclic Aromatic Hydrocarbons (PAHs) in the Continental Shelf of China: Implications for Evolving Anthropogenic Impacts. Environmental Science \& Technology, 46(12), 6497-6504. https://doi.org/10.1021/es300474z

Losno, R., Bergametti, G., Carlier, P., \& Mouvier, G. (1991). Major ions in marine rainwater with attention to sources of alkaline and acidic species. Atmospheric Environment Part A, General Topics, 25(3-4), 763-770. https://doi.org/10.1016/0960-1686(91)90074-H

MacKey, K. R. M., Roberts, K., Lomas, M. W., Saito, M. A., Post, A. F., \& Paytan, A. (2012). Enhanced solubility and ecological impact of atmospheric phosphorus deposition upon extended seawater exposure. Environmental Science and Technology, 46(19), 10438-10446. https://doi.org/10.1021/es3007996

Markaki, Z., Oikonomou, K., Kocak, M., Kouvarakis, G., Chaniotaki, A., Kubilay, N., \& Mihalopoulos, N. (2003). Atmospheric deposition of inorganic phosphorus in the Levantine Basin, eastern Mediterranean: Spatial and temporal variability and its role in seawater productivity. Limnology and Oceanography, 48(4), 1557-1568. https://doi.org/ 10.4319/10.2003.48.4.1557

Martin, S. T., Schlenker, J. C., Malinowski, A., Hung, H. M., \& Rudich, Y. (2003). Crystallization of atmospheric sulfate-nitrate-ammonium particles. Geophysical Research Letters, 30(21).https://doi.org/10.1029/2003GL017930

Mashburn, C. D. (2006). Laboratory studies on the heterogeneous chemistry of clay minerals in the earth's atmosphere. Ph.D Thesis, University of Colorado at Boulder.

Meskhidze, N. (2003). Iron mobilization in mineral dust: Can anthropogenic $\mathrm{SO}_{2}$ emissions affect ocean productivity? Geophysical Research Letters. https://doi.org/10.1029/2003GL018035

Moise, T., Talukdar, R. K., Frost, G. J., Fox, R. W., \& Rudich, Y. (2002). Reactive uptake of $\mathrm{NO}_{3}$ by liquid and frozen organics. Journal of Geophysical Research-Atmospheres, 107(1-2). https://doi.org/4014 10.1029/2001jd000334

Nakamura, T., Matsumoto, K., \& Uematsu, M. (2005). Chemical characteristics of aerosols transported from Asia to 
Atmos. Chem. Phys. Discuss., https://doi.org/10.5194/acp-2018-985

Manuscript under review for journal Atmos. Chem. Phys.

Discussion started: 6 December 2018

(c) Author(s) 2018. CC BY 4.0 License.

the East China Sea: An evaluation of anthropogenic combined nitrogen deposition in autumn. Atmospheric Environment, 39(9), 1749-1758. https://doi.org/10.1016/j.atmosenv.2004.11.037

Nenes, A., Krom, M. D., Mihalopoulos, N., Van Cappellen, P., Shi, Z., Bougiatioti, A., ... Herut, B. (2011). Atmospheric acidification of mineral aerosols: A source of bioavailable phosphorus for the oceans. Atmospheric Chemistry and Physics, 11(13), 6265-6272. https://doi.org/10.5194/acp-11-6265-2011

Oelkers, E. H., \& Schott, J. (2001). An experimental study of enstatite dissolution rates as funcion of $\mathrm{pH}$, temperature, and aqueous $\mathrm{Mg}$ and $\mathrm{Si}$ concentration, and the mechanism of pyroxene/pyroxenoid dissolution. Geochimica et Cosmochimica Acta, 65(8), 1219-1231. https://doi.org/10.1016/S0016-7037(00)00564-0

Pakkanen, T. A. (1996). Study of formation of coarse particle nitrate aerosol. Atmospheric Environment, 30(14), 2475-2482. https://doi.org/10.1016/1352-2310(95)00492-0

Park, Y., Choi, J., \& Gao, S. (2001). Spatial variation of suspended particulate matter in the Yellow Sea. Geo-Marine Letters, 20(4), 196-200. https://doi.org/10.1007/s003670000055

Qi, J., Zhang, R., Chen, X., Lin, X., Gao, H., \& Liu, R. (2017). The concentration, source apportionment and deposition flux of atmospheric particulate inorganic nitrogen during dust events. Atmospheric Chemistry and Physics Discussions, 18(February), 1-20. https://doi.org/10.5194/acp-2016-1183

Ruttenberg, K. C. (1992). Development of a sequential extraction method for different forms of phosphorus in marine sediments. Limnology and Oceanography, 37(7), 1460-1482. https://doi.org/10.4319/1o.1992.37.7.1460

Saathoff, H., Naumann, K. H., Schnaiter, M., Schöck, W., Möhler, O., Schurath, U., ... Baltensperger, U. (2003). Coating of soot and $\left(\mathrm{NH}_{4}\right)_{2} \mathrm{SO}_{4}$ particles by ozonolysis products of $\alpha$-pinene. Journal of Aerosol Science, 34(10), 1297-1321. https://doi.org/10.1016/S0021 -8502(03)00364-1

Schott, J., Berner, R. A., \& Sjöberg, E. L. (1981). Mechanism of pyroxene and amphibole weathering-I. Experimental studies of iron-free minerals. Geochimica et Cosmochimica Acta, 45(11), 2123-2135. https://doi.org/10.1016/0016-7037(81)90065-X

Shi, J., Gao, H., Qi, J., Zhang, J., \& Yao, X. (2010). Sources, compositions, and distributions of water-soluble organic nitrogen in aerosols over the China Sea. Journal of Geophysical Research Atmospheres, 115(17). https://doi.org/10.1029/2009JD013238

Shi, Z., Krom, M. D., Bonneville, S., Baker, A. R., Jickells, T. D., \& Benning, L. G. (2009). Formation of iron nanoparticles and increase in iron reactivity in mineral dust during simulated cloud processing. Environmental Science and Technology, 43(17), 6592-6596. https://doi.org/10.1021/es901294g

Siswanto, E. (2015). Atmospheric deposition - Another source of nutrients enhancing primary productivity in the eastern tropical Indian Ocean during positive Indian Ocean Dipole phases. Geophysical Research Letters, 42(13), 5378-5386. https://doi.org/10.1002/2015GL064188

Stockdale, A., Krom, M. D., Mortimer, R. J. G., Benning, L. G., Carslaw, K. S., Herbert, R. J., ... Nenes, A. (2016). Understanding the nature of atmospheric acid processing of mineral dusts in supplying bioavailable phosphorus to the oceans. Proceedings of the National Academy of Sciences, 113(51), 14639-14644. https://doi.org/10.1073/pnas.1608136113

Suzuki, I., Igarashi, Y., Dokiya, Y., \& Akagi, T. (2010). Two extreme types of mixing of dust with urban aerosols 
Atmos. Chem. Phys. Discuss., https://doi.org/10.5194/acp-2018-985

Manuscript under review for journal Atmos. Chem. Phys.

Discussion started: 6 December 2018

(c) Author(s) 2018. CC BY 4.0 License.

observed in Kosa particles: "After" mixing and "on-the-way" mixing. Atmospheric Environment, 44(6), 858-866. https://doi.org/10.1016/j.atmosenv.2009.11.030

Tang, R., Henneman, Z. J., \& Nancollas, G. H. (2003). Constant composition kinetics study of carbonated apatite dissolution. Journal of Crystal Growth, 249(3-4), 614-624. https://doi.org/10.1016/S0022-0248(02)02332-1

Tao, S. Y. (1987). A review of recent research on the East Asian summer monsoon in China. Monsoon Meteorology, 60-92.

Tréguer, P. J., \& De La Rocha, C. L. (2013). The World Ocean Silica Cycle. Annual Review of Marine Science, 5(1), 477-501. https://doi.org/10.1146/annurev-marine-121211-172346

Truesdale, V. W., Greenwood, J. E., \& Rendell, A. R. (2005). In vitro, batch-dissolution of biogenic silica in seawater The application of recent modelling to real data. Progress in Oceanography, 66(1), 1-24. https://doi.org/10.1016/j.pocean.2005.02.019

Uno, I., Eguchi, K., Yumimoto, K., Takemura, T., Shimizu, A., Uematsu, M., ... Sugimoto, N. (2009). Asian dust transported one full circuit around theglobe. Nature Geoscience, 2(8), 557-560. https://doi.org/10.1038/ngeo583

Valsami-Jones, E., Rggnarsdottir, K. V., Putnis, A., Bosbach, D., Kemp, A. J., \& Cressey, G. (1998). The dissolution of apatite in the presence of aqueous metal cations at pH 2-7. Chemical Geology, 151(1-4), 215-233. https://doi.org/10.1016/S0009-2541(98)00081-3

Wang, H., Li, J. L., Zhang, H. H., \& Yang, G. P. (2018). Chemical compositions and characteristics of main water-soluble ions in aerosols in the western Yellow Sea in winter. Marine Environmental Science (3). (in Chinese version)

Wang, L., Bi, Y., Zhang, G., Liu, S., Zhang, J., Xu, Z., ... Zhang, G. (2017). Simulated nutrient dissolution of Asian aerosols in various atmospheric waters: Potential links to marine primary productivity. Atmospheric Environment, 164, 224-238. https://doi.org/10.1016/j.atmosenv. 2017.06.005

Yang, G. P., \& Xiu, L. P. (2009). Chemical characteristics of aerosol-bound ionic species over the southern coastal area of Shandong Peninsula. Journal of Ocean University of China (natural science edition), 39(4), 745-749. (in Chinese version)

Yuan, Z., Jiang, S., Sheng, H., Liu, X., Hua, H., Liu, X., \& Zhang, Y. (2018). Human Perturbation of the Global Phosphorus Cycle: Changes and Consequences. Environmental Science and Technology, 52(5), 2438-2450. https://doi.org/10.1021/acs.est.7b03910

Zhang, J., Zhang, G. S., Bi, Y. F., \& Liu, S. M. (2011). Nitrogen species in rainwater and aerosols of the Yellow and East China seas: Effects of the East Asian monsoon and anthropogenic emissions and relevance for the NW Pacific Ocean. Global Biogeochemical Cycles, 25(3). https://doi.org/10.1029/2010GB003896

Zhang, K., Wang, Z., Li, W., \& Yan, J. (2018). Properties of coarse particles in suspended particulate matter of the north yellow sea during summer. Journal of Oceanology \& Limnology, 1-14. https://doi.org/10.1007/s00343-019-7153-X

Zheng, J. J., Gao, S. Q., Chen, J. F., Zhu, Y., Jin, H. Y., \& Zhong-Qiang, J. I. (2011). Distribution of water-soluble ions in atmospheric aerosol of Changjiang river estuary and east china sea. Journal of Marine Sciences. (in Chinese version) 
Atmos. Chem. Phys. Discuss., https://doi.org/10.5194/acp-2018-985

Manuscript under review for journal Atmos. Chem. Phys.

Discussion started: 6 December 2018

(c) Author(s) 2018. CC BY 4.0 License.

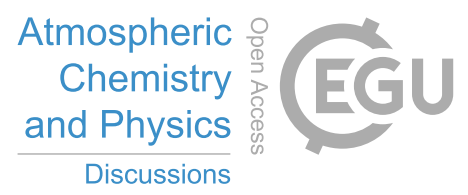

(c) (1)

Zhuang, Guoshun, Duce, Robert A., Kester, D. R. (1990). The Dissolution of Atmospheric Iron in Surface Seawater of the Open Ocean. Journal of Geophysical Research, 95(C9), 16207-16216. https://doi.org/10.1029 /JC095iC09p16207 


\section{Appendices}

\section{Figures:}

Fig. 1. -72h back-trajectories of air-masses of six aerosols for high time-resolution nutrient dissolution experiments.

Fig. 2. A schematic diagram of high time-resolution dissolution experiment.

680 Fig. 3. (a) Concentrations of $\mathrm{P}$ species in aerosols by SEDEX method. (b) Relative fractions of inorganic P species.

Fig. 4. Linear relationships between water-soluble and acid-soluble (a) $\mathrm{NO}_{3}{ }^{-}$and $\mathrm{NH}_{4}{ }^{+}$concentrations and (b) $\mathrm{PO}_{4}{ }^{3-}$ and $\mathrm{SiO}_{3}{ }^{2-}$ concentrations in ultra-sound extractions (square) and high time-resolution dissolution experiments (triangle).

685 Fig. 5. Accumulated dissolution curves for high time-resolution dissolution experiments.

Fig. 6. Accumulated $\mathrm{P} / \mathrm{Si}$ ratio curves for high time-resolution dissolution experiments.

Fig. 7. P solubility curves for high time-resolution dissolution experiments.

Fig. 8. Accumulated $\mathrm{NH}_{4}{ }^{+} / \mathrm{NO}_{3}{ }^{-}$ratio curves for high time-resolution dissolution experiments. 
Atmos. Chem. Phys. Discuss., https://doi.org/10.5194/acp-2018-985

Manuscript under review for journal Atmos. Chem. Phys.

Discussion started: 6 December 2018

(c) Author(s) 2018. CC BY 4.0 License.

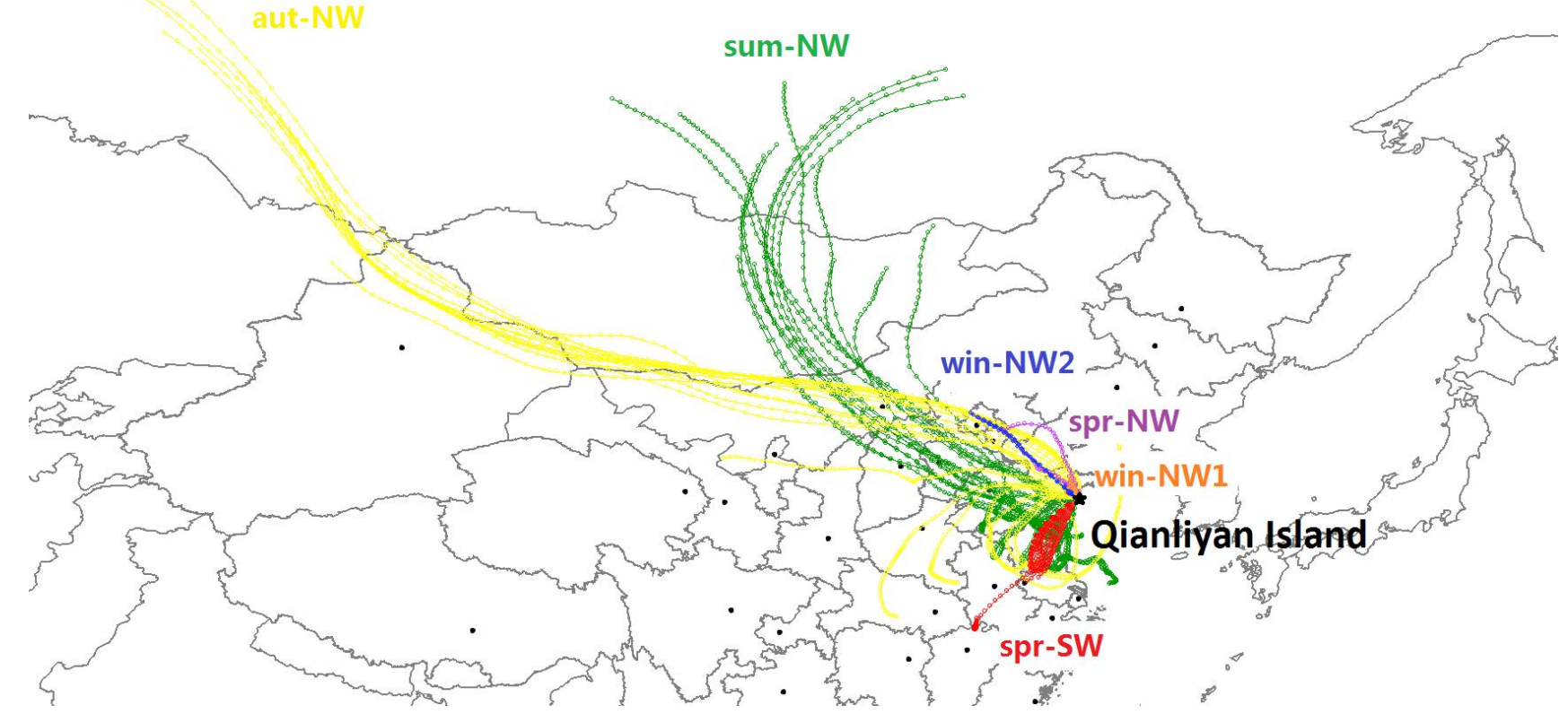

Fig. 1 
Atmos. Chem. Phys. Discuss., https://doi.org/10.5194/acp-2018-985

Manuscript under review for journal Atmos. Chem. Phys.

Discussion started: 6 December 2018

(c) Author(s) 2018. CC BY 4.0 License.

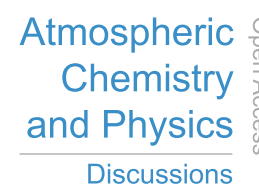

(c) (1)

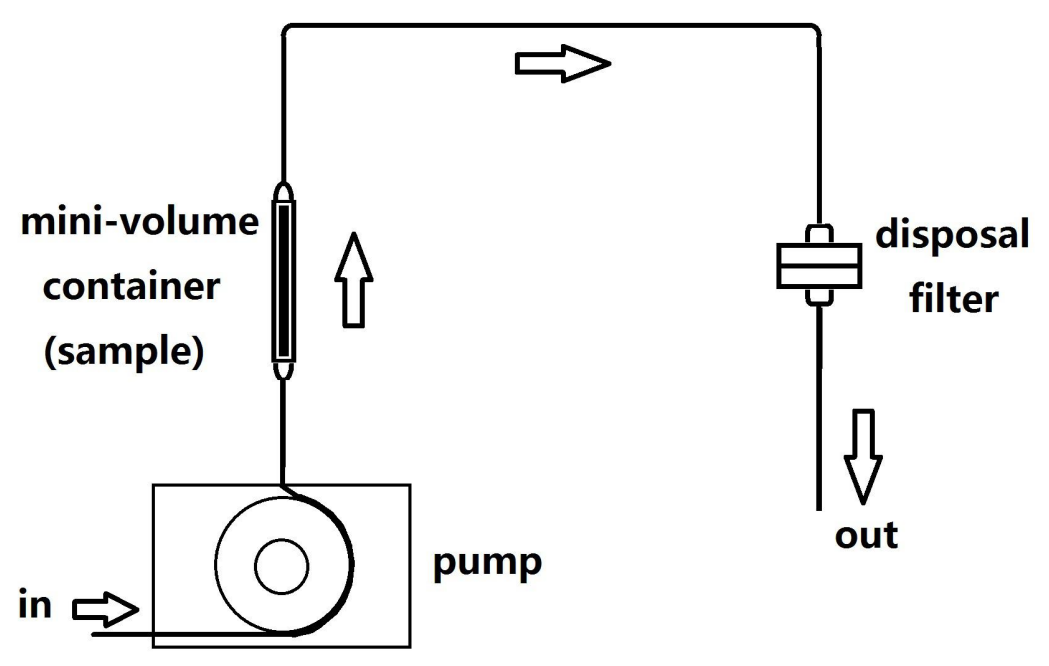

Fig. 2 
Atmos. Chem. Phys. Discuss., https://doi.org/10.5194/acp-2018-985

Manuscript under review for journal Atmos. Chem. Phys.

Discussion started: 6 December 2018

(c) Author(s) 2018. CC BY 4.0 License.
Atmospheric

Chemistry

and Physics

Discussions

(c) (1)

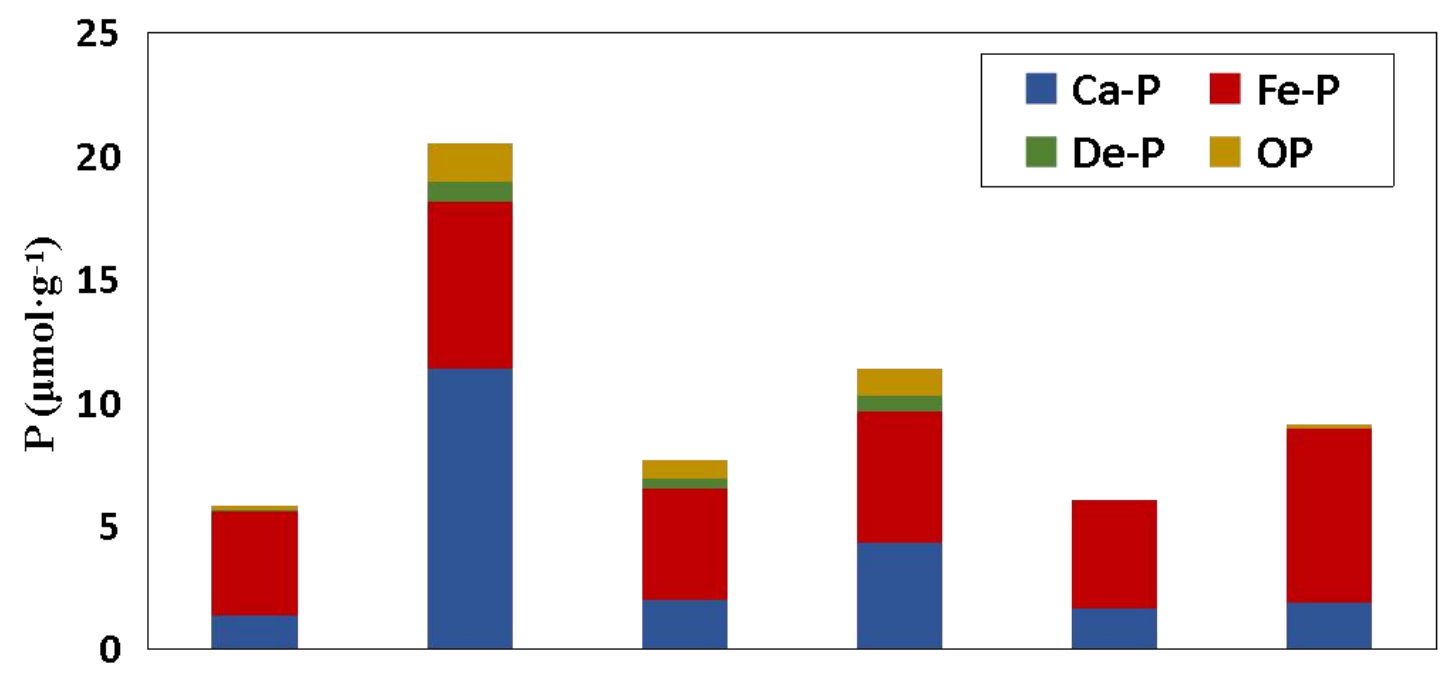

(a)

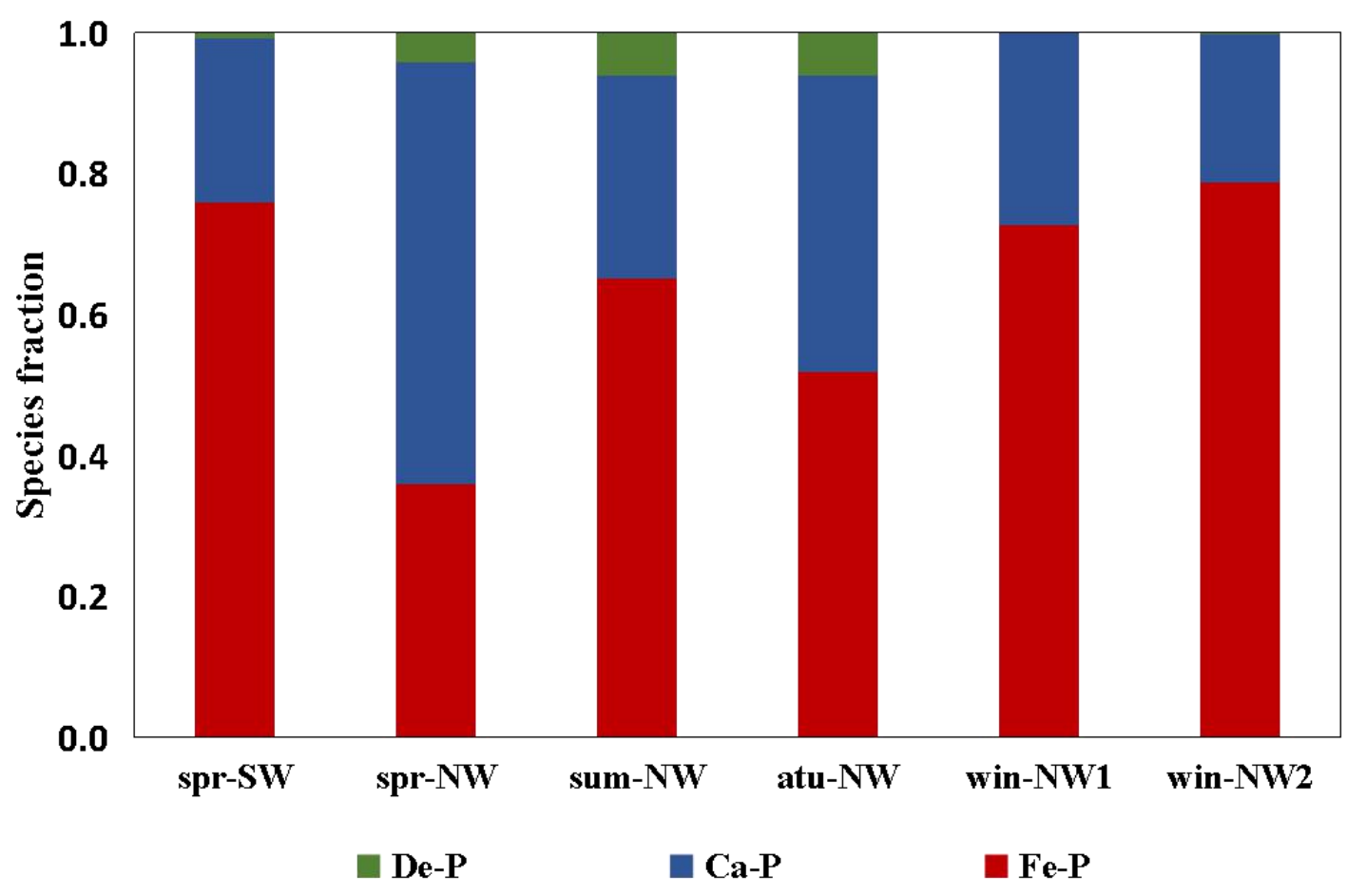

(b)

Fig. 3 
Atmos. Chem. Phys. Discuss., https://doi.org/10.5194/acp-2018-985

Manuscript under review for journal Atmos. Chem. Phys.

Discussion started: 6 December 2018

(c) Author(s) 2018. CC BY 4.0 License.

(c) (i)
Atmospheric

Chemistry and Physics

Discussions

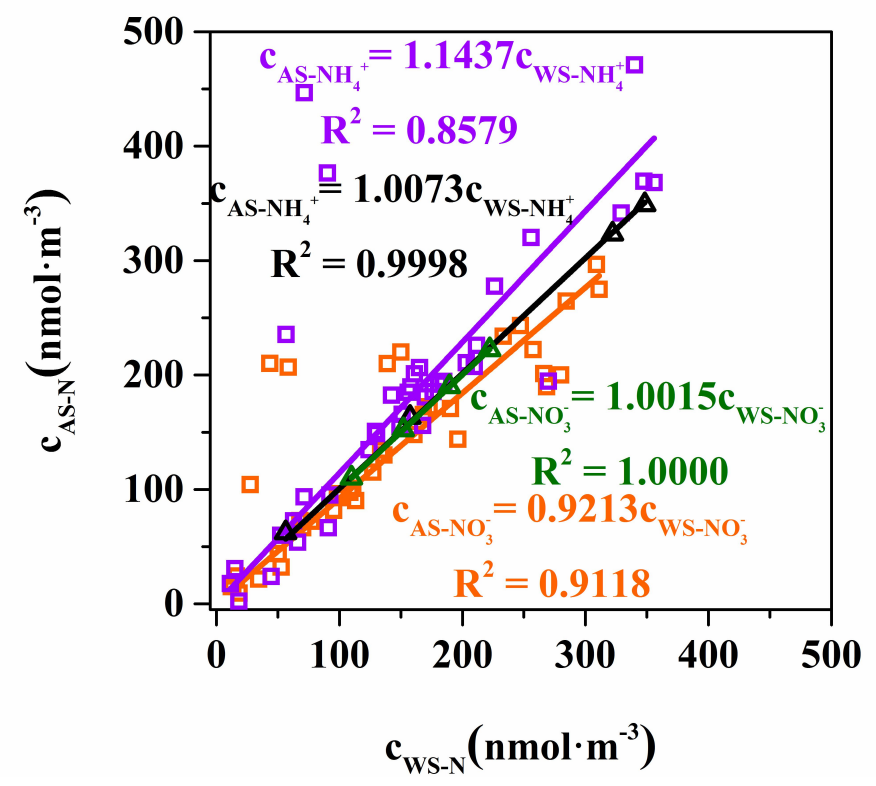

(a)

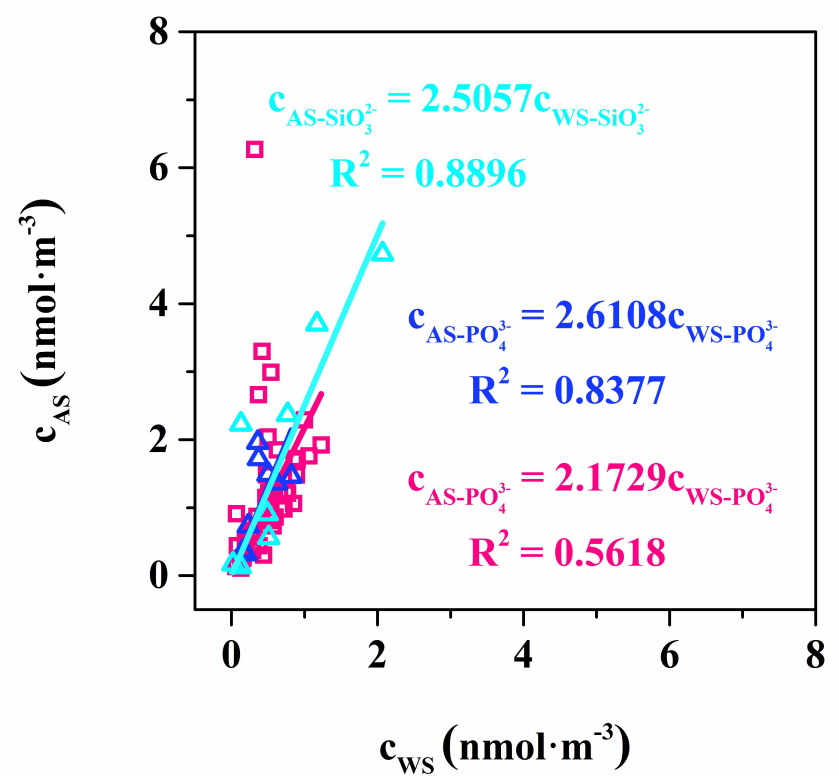

(b)

Fig. 4 
Atmos. Chem. Phys. Discuss., https://doi.org/10.5194/acp-2018-985

Manuscript under review for journal Atmos. Chem. Phys.

Discussion started: 6 December 2018

(c) Author(s) 2018. CC BY 4.0 License.

\section{(c) (1)}
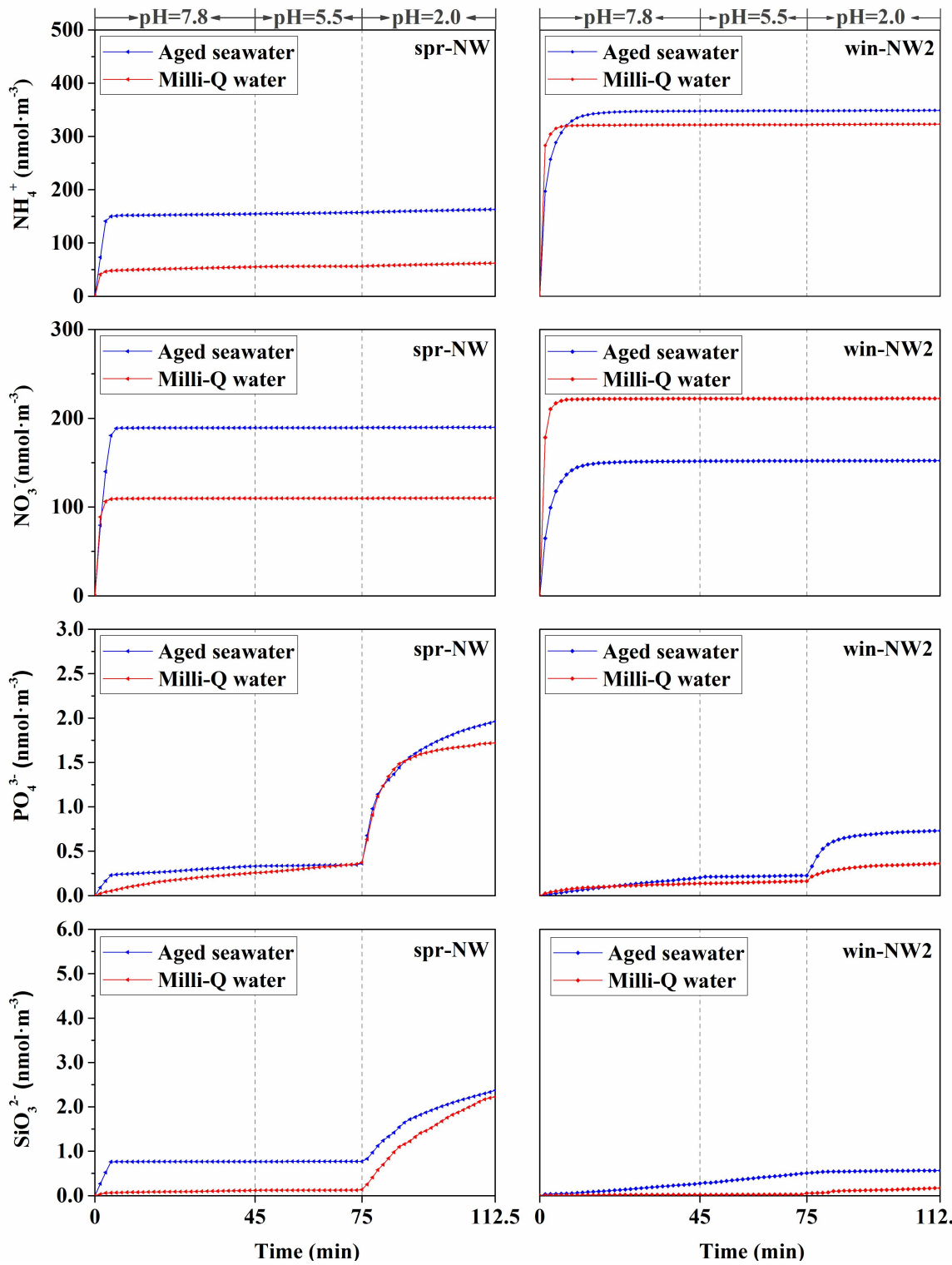

Fig. 5

\section{Atmospheric \\ Chemistry \\ and Physics \\ Discussions}
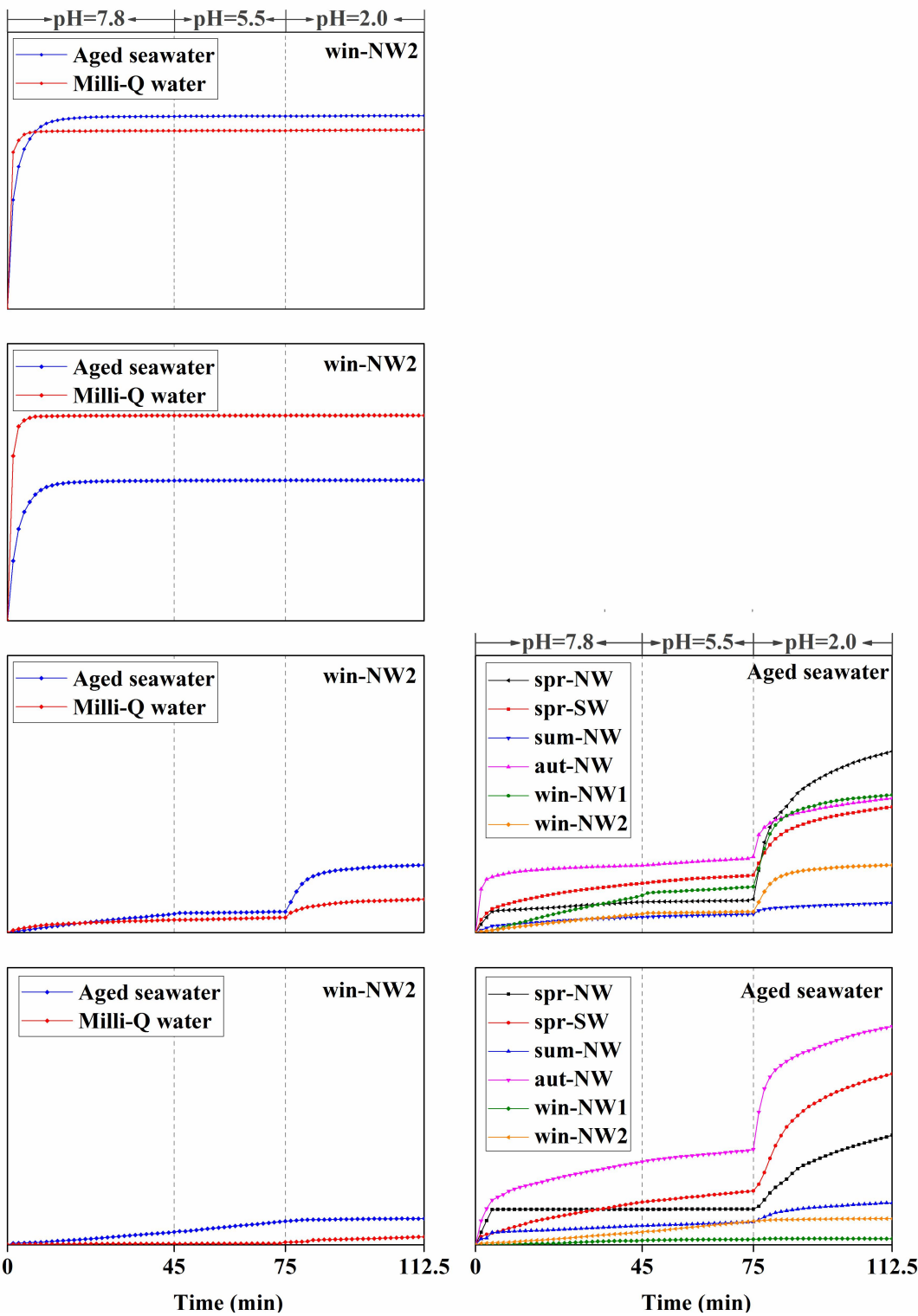
Atmos. Chem. Phys. Discuss., https://doi.org/10.5194/acp-2018-985

Manuscript under review for journal Atmos. Chem. Phys.

Discussion started: 6 December 2018

(c) Author(s) 2018. CC BY 4.0 License.

(c) (i)

\section{Atmospheric \\ Chemistry \\ and Physics \\ Discussions}
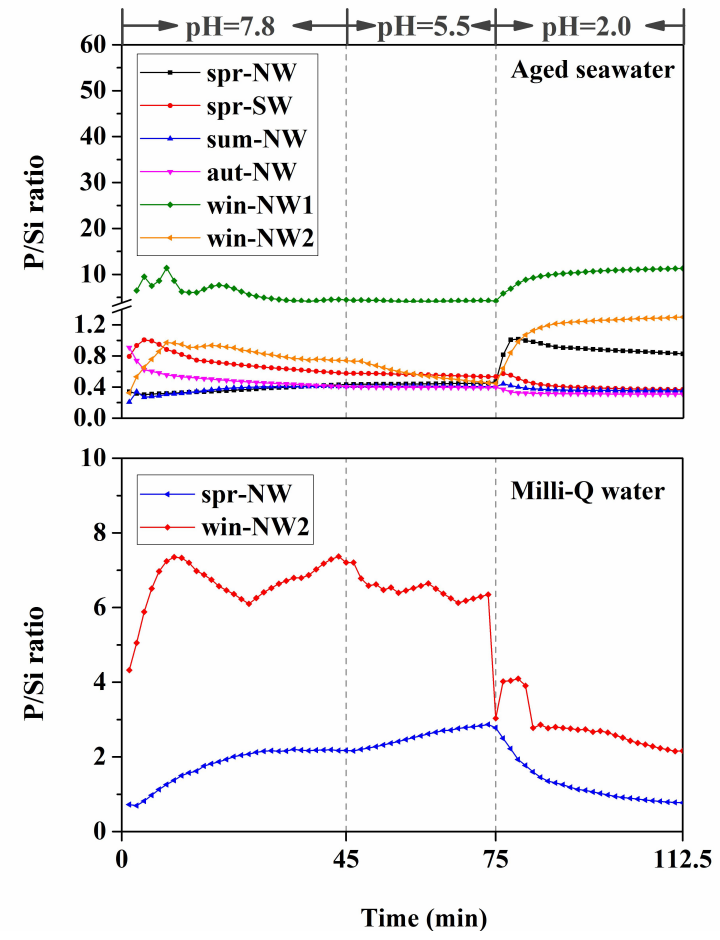

Fig. 6 
Atmos. Chem. Phys. Discuss., https://doi.org/10.5194/acp-2018-985

Manuscript under review for journal Atmos. Chem. Phys.

Discussion started: 6 December 2018

(c) Author(s) 2018. CC BY 4.0 License.

(c) (i)

\section{Atmospheric \\ Chemistry \\ and Physics \\ Discussions}
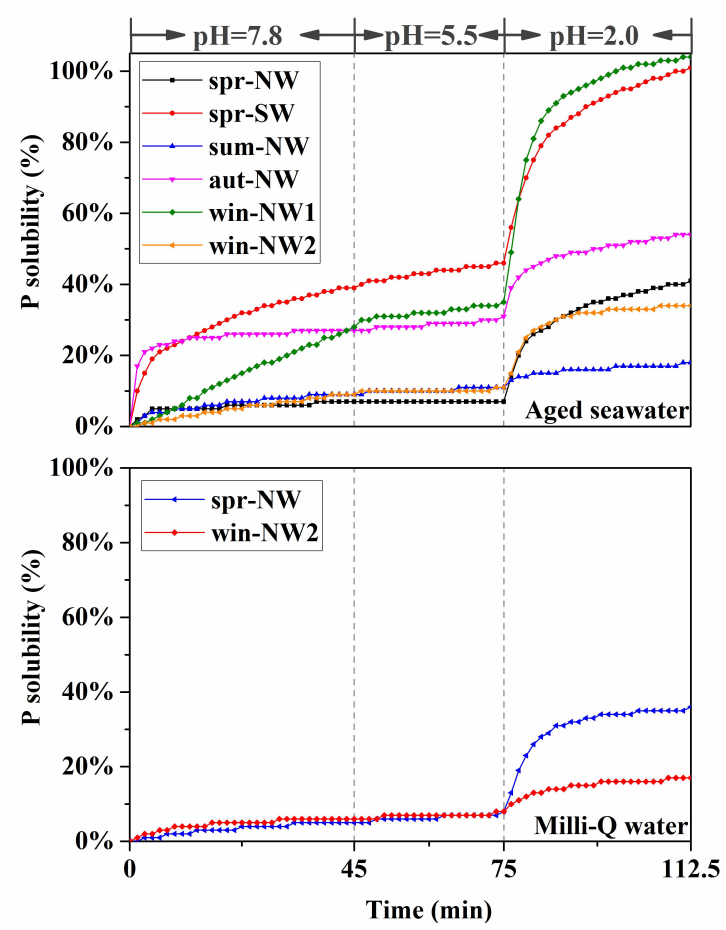

Fig. 7 
Atmos. Chem. Phys. Discuss., https://doi.org/10.5194/acp-2018-985

Manuscript under review for journal Atmos. Chem. Phys.

Discussion started: 6 December 2018

(c) Author(s) 2018. CC BY 4.0 License.

(c) (i)

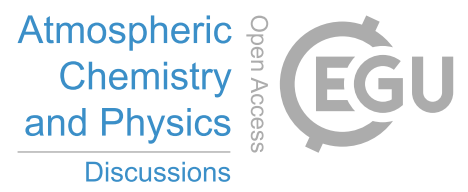

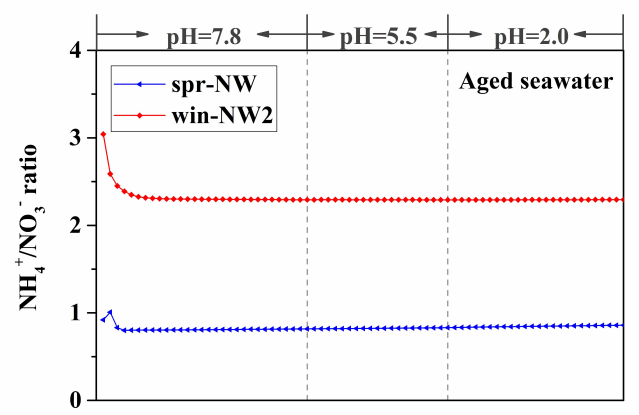

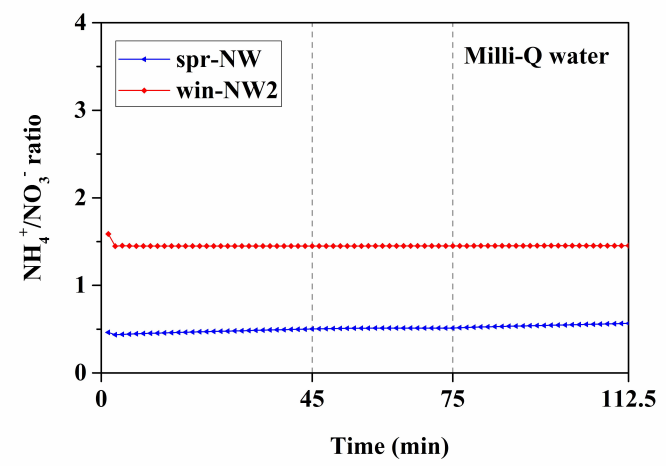

Fig. 8 
Atmos. Chem. Phys. Discuss., https://doi.org/10.5194/acp-2018-985

Manuscript under review for journal Atmos. Chem. Phys.

Discussion started: 6 December 2018

(c) Author(s) 2018. CC BY 4.0 License.
Atmospheric 을

Chemistry

and Physics

Discussions

720 Table 1. One-stage aerosol $\mathrm{NH}_{4}{ }^{+}$and $\mathrm{NO}_{3}{ }^{-}$dissolution kinetic parameters for high time-resolution dissolution experiments, which included dissolution rate constant $\left(\mathrm{k}, \mathrm{min}^{-1}\right)$, reached dissolution equilibrium time $\left(\mathrm{t}_{\mathrm{e}}, \mathrm{min}\right)$ and accumulated $\mathrm{NH}_{4}{ }^{+}$and $\mathrm{NO}_{3}{ }^{-}$concentrations $\left(\mathrm{nmol} \cdot \mathrm{m}^{-3}\right)$ at dissolution equilibrium time $\left(\mathrm{c}_{\mathrm{e}}\right), \mathrm{pH} 7.8\left(\mathrm{c}_{45}\right), \mathrm{pH} 5.5\left(\mathrm{c}_{75}\right)$ and $\mathrm{pH} 2.0\left(\mathrm{c}_{112.5}\right)$.

\begin{tabular}{cccccccc}
\hline & $\mathbf{k}$ & $\mathbf{n}$ & $\mathbf{t}_{\mathbf{e}}$ & $\mathbf{c}_{\mathbf{e}}$ & $\mathbf{c}_{\mathbf{4 5}}$ & $\mathbf{c}_{\mathbf{7 5}}$ & $\mathbf{c}_{\mathbf{1 1 2 . 5}}$ \\
\hline Milli-Q water-soluble $\mathrm{NH}_{4}{ }^{+}$ & & & & & & & \\
spr-NW & 1.24 & 0.32 & 6 & 48.5 & 55.1 & 56.3 & 62.3 \\
win-NW2 & 1.65 & 0.56 & 6 & 318.6 & 321.8 & 322.1 & 323.2 \\
\hline Aged seawater-soluble $\mathrm{NH}_{4}{ }^{+}$ & & & & & & & \\
spr-NW & 0.44 & 1.31 & 6 & 151.0 & 154.7 & 157.4 & 163.1 \\
win-NW2 & 0.64 & 0.68 & 6 & 307.0 & 347.8 & 348.3 & 349.1 \\
\hline Milli-Q water-soluble $\mathrm{NO}_{3}{ }^{-}$ & & & & & & & \\
spr-NW & 1.31 & 0.79 & 7.5 & 109.5 & 109.8 & 109.9 & 110.1 \\
win-NW2 & 1.27 & 0.71 & 7.5 & 220.8 & 222.1 & 222.1 & 222.3 \\
\hline Aged seawater-soluble $\mathrm{NO}_{3}{ }^{-}$ & & & & & & & \\
spr-NW & 0.25 & 1.67 & 7.5 & 189.1 & 189.3 & 189.4 & 189.9 \\
win-NW2 & 0.40 & 0.88 & 7.5 & 136.5 & 151.6 & 152.0 & 152.2 \\
\hline
\end{tabular}


Table 2. Three-stage aerosol $\mathrm{PO}_{4}{ }^{3-}$ and $\mathrm{SiO}_{3}{ }^{2-}$ dissolution kinetic parameters for high time-resolution dissolution experiments, which included dissolution rate constant $\left(\mathrm{k}_{1}, \mathrm{k}_{2}\right.$ and $\left.\mathrm{k}_{3}, \min ^{-1}\right)$, reached dissolution equilibrium time ( $\mathrm{t}_{\mathrm{e} 1}$ and $\mathrm{t}_{\mathrm{e} 3}$, min) and accumulated $\mathrm{PO}_{4}{ }^{3-}$ and $\mathrm{SiO}_{3}{ }^{2-}$ concentrations $\left(\mathrm{nmol} \cdot \mathrm{m}^{-3}\right)$ at dissolution equilibrium time $\left(\mathrm{c}_{\mathrm{e} 1}\right.$ and $\left.\mathrm{c}_{\mathrm{e} 3}\right)$, $\mathrm{pH} 7.8\left(\mathrm{c}_{45}\right), \mathrm{pH} 5.5\left(\mathrm{c}_{75}\right)$ and $\mathrm{pH} 2.0\left(\mathrm{c}_{112.5}\right)$. "_." represented a special case that win-NW1 sample had no further $\mathrm{SiO}_{3}{ }^{2-}$ dissolution in strong acidic aged seawater.

\begin{tabular}{|c|c|c|c|c|c|c|c|c|c|c|c|}
\hline & $\mathbf{k}_{1}$ & $\mathbf{n}_{1}$ & $\mathbf{t}_{\mathrm{e} 1}$ & $\mathbf{c}_{\mathrm{e} 1}$ & $\mathbf{c}_{45}$ & $\mathbf{k}_{\mathbf{2}}$ & $\mathbf{c}_{75}$ & $\mathbf{k}_{\mathbf{3}}$ & $\mathbf{n}_{3}$ & $\mathbf{t}_{\mathbf{e}}$ & $\mathbf{c}_{\mathrm{e} 3}$ \\
\hline \multicolumn{12}{|c|}{ Milli-Q water-soluble $\mathrm{PO}_{4}{ }^{3-}$} \\
\hline spr-NW & 0.05 & 1.01 & 37.5 & 0.23 & 0.26 & 0.054 & 0.26 & 0.20 & 0.88 & 106.5 & 1.69 \\
\hline win-NW2 & 0.14 & 0.78 & 37.5 & 0.13 & 0.14 & 0.008 & 0.16 & 0.21 & 0.76 & 106.5 & 0.35 \\
\hline \multicolumn{12}{|c|}{ Aged seawater-soluble $\mathrm{PO}_{4}^{3-}$} \\
\hline spr-SW & 0.22 & 0.66 & 37.5 & 0.50 & 0.53 & 0.030 & 0.62 & 0.15 & 0.85 & 106.5 & 1.33 \\
\hline spr-NW & 0.37 & 0.53 & 37.5 & 0.32 & 0.33 & 0.064 & 0.36 & 0.15 & 0.85 & 106.5 & 1.90 \\
\hline sum-NW & 0.13 & 0.78 & 37.5 & 0.16 & 0.17 & 0.005 & 0.20 & 0.27 & 0.62 & 106.5 & 0.31 \\
\hline atu-NW & 0.90 & 0.42 & 37.5 & 0.72 & 0.73 & 0.025 & 0.82 & 0.34 & 0.59 & 106.5 & 1.43 \\
\hline win-NW1 & 0.01 & 1.44 & 42 & 0.37 & 0.40 & 0.040 & 0.50 & 0.34 & 0.59 & 106.5 & 1.47 \\
\hline win-NW2 & 0.02 & 1.19 & 42 & 0.19 & 0.20 & 0.020 & 0.23 & 0.22 & 0.85 & 106.5 & 0.72 \\
\hline \multicolumn{12}{|c|}{ Milli-Q water-soluble $\mathrm{SiO}_{3}^{2-}$} \\
\hline spr-NW & 0.32 & 0.49 & 39 & 0.11 & 0.12 & 0.084 & 0.13 & 0.04 & 1.16 & 106.5 & 2.05 \\
\hline win-NW2 & 0.32 & 0.54 & 22.5 & 0.02 & 0.02 & 0.005 & 0.05 & 0.10 & 0.83 & 106.5 & 0.15 \\
\hline \multicolumn{12}{|c|}{ Aged seawater-soluble $\mathrm{SiO}_{3}{ }^{2-}$} \\
\hline spr-SW & 0.10 & 0.77 & 37.5 & 0.82 & 0.92 & 0.101 & 1.17 & 0.05 & 1.19 & 106.5 & 3.57 \\
\hline spr-NW & 0.20 & 1.87 & 7.5 & 0.76 & 0.77 & 0.064 & 0.77 & 0.03 & 1.26 & 106.5 & 2.24 \\
\hline sum-NW & 0.33 & 0.54 & 37.5 & 0.38 & 0.41 & 0.017 & 0.49 & 0.10 & 0.95 & 106.5 & 0.89 \\
\hline atu-NW & 0.28 & 0.59 & 37.5 & 1.69 & 1.80 & 0.106 & 2.07 & 0.30 & 0.65 & 106.5 & 4.63 \\
\hline win-NW1 & 0.00 & 1.52 & 37.5 & 0.08 & 0.09 & 0.001 & 0.12 & - & - & - & - \\
\hline win-NW2 & 0.03 & 1.01 & 42 & 0.25 & 0.27 & 0.002 & 0.51 & 0.13 & 0.96 & 106.5 & 0.56 \\
\hline
\end{tabular}


Atmos. Chem. Phys. Discuss., https://doi.org/10.5194/acp-2018-985

Manuscript under review for journal Atmos. Chem. Phys.

Discussion started: 6 December 2018

(C) Author(s) 2018. CC BY 4.0 License.

(c) (i)
Atmospheric

Chemistry

and Physics

Discussions

Table 3. Person correlation coefficients for aged seawater-soluble $\mathrm{P}$ solubility (SWPS, \%), aged seawater acid-soluble $\mathrm{P}$ solubility (SAPS, \%), dissolution rate constant $\left(\mathrm{k}_{1}, \mathrm{k}_{2}\right.$ and $\left.\mathrm{k}_{3}, \mathrm{~min}^{-1}\right)$, TSP mass concentration $\left(\mu \mathrm{g} \cdot \mathrm{m}^{-3}\right)$ and TP, Fe-P, Ca-P and De-P concentrations $\left(\mathrm{nmol} \cdot \mathrm{m}^{-3}\right)$.

\begin{tabular}{|c|c|c|c|c|c|c|c|c|c|c|}
\hline & SWPS & SAPS & k1 & k2 & k3 & TSP & TP & Fe-P & Ca-P & De-P \\
\hline SWPS & 1 & & & & & & & & & \\
\hline SAPS & $0.872^{*}$ & 1 & & & & & & & & \\
\hline k1 & 0.197 & -0.112 & 1 & & & & & & & \\
\hline k2 & 0.098 & 0.387 & 0.212 & 1 & & & & & & \\
\hline k3 & 0.149 & 0.072 & 0.229 & -0.278 & 1 & & & & & \\
\hline TSP & -0.755 & -0.547 & 0.088 & 0.532 & -0.448 & 1 & & & & \\
\hline $\mathbf{T P}$ & -0.556 & -0.439 & 0.403 & 0.642 & -0.364 & $0.934^{* *}$ & 1 & & & \\
\hline $\mathrm{Fe}-\mathrm{P}$ & -0.677 & -0.539 & 0.066 & 0.35 & -0.357 & $0.829^{*}$ & 0.705 & 1 & & \\
\hline Ca-P & -0.459 & -0.314 & 0.385 & 0.719 & -0.379 & $0.893^{*}$ & $0.984^{* *}$ & 0.588 & 1 & \\
\hline De-P & -0.434 & -0.541 & 0.688 & 0.317 & -0.071 & 0.654 & $0.834^{*}$ & 0.348 & $0.825^{*}$ & 1 \\
\hline
\end{tabular}

${ }^{*}$ Significant at 0.01

** Significant at 0.01 